Portland State University

PDXScholar

\title{
"Heaven's Last, Worst Gift to White Men": The Quadroons of Antebellum New Orleans
}

Erin Elizabeth McCullugh

Portland State University

Follow this and additional works at: https://pdxscholar.library.pdx.edu/open_access_etds

Part of the Social History Commons, United States History Commons, and the Women's History Commons

Let us know how access to this document benefits you.

\section{Recommended Citation}

McCullugh, Erin Elizabeth, "'Heaven's Last, Worst Gift to White Men": The Quadroons of Antebellum New Orleans" (2010). Dissertations and Theses. Paper 3269.

https://doi.org/10.15760/etd.3264

This Thesis is brought to you for free and open access. It has been accepted for inclusion in Dissertations and Theses by an authorized administrator of PDXScholar. Please contact us if we can make this document more accessible: pdxscholar@pdx.edu. 


\begin{abstract}
An abstract of the thesis of Erin Elizabeth McCullugh for the Master of Arts in History presented April 30, 2010.
\end{abstract}

Title: "Heaven's last, worst gift to white men:" The Quadroons of Antebellum New Orleans

Visitors to Antebellum New Orleans rarely failed to comment on the highly visible population of free persons of color, particularly the women. Light, but not white, the women who collectively became known as Quadroons enjoyed a degree of affluence and liberty largely unknown outside of Southeastern Louisiana. The Quadroons of New Orleans, however, suffered from neglect and misrepresentation in nineteenth and twentieth-century accounts.

Historians of slavery and southern black women, for example, have written at length on the sexual experiences of black women and white men. Most of the research, however, centers on the institutionalized rape, victimization, and exploitation of black women at the hands of white males. Even late into the twentieth century, scholars largely failed to distinguish the experiences of free women of color from those of enslaved women with little nuance in regard to economic, educational, and cultural differences. All women of color-whether free or enslaved - continued to be viewed through the lens of slavery. Studies that examine free women of color were rare and 
those focusing exclusively on them alone were virtually nonexistent. As a result, the actual experiences of free women of color in the Gulf States passed unnoticed for generations. In the event that the Quadroons of New Orleans were mentioned at all, it was normally within the context of the mythologized balls or in scandalous tales where they played the role of mistress to white men, subsequently resulting in a onedimensional character that lived expressly for the enjoyment of white males.

Due to the relative silence of their own voices, approaching the topic of New Orleans' Quadroons at length is difficult at best. But by placing these women within a wider pan-Atlantic framework and using extant legal records, the various African, Caribbean, French, and Spanish cultural threads emerge that contributed to the colorful cultural tapestry of Antebellum New Orleans. These influences enabled such practices as plaçage and by extension, the development of an intellectual, wealthy, vibrant Creole community of color headed by women. 


\title{
"HEAVEN'S LAST, WORST GIFT TO WHITE MEN:" \\ THE QUADROONS OF ANTEBELLUM NEW ORLEANS
}

\author{
by
}

Erin Elizabeth McCullugh

A thesis submitted in partial fulfillment of the requirements for the degree of

\author{
MASTER OF ARTS \\ in \\ HISTORY
}

Thesis Committee:

David A. Horowitz, Chair

James Grehan

Tim Garrison

José Padín

Portland State University

(C)2010 
For my mother-a woman of great strength and kindness. Thank you for showing me how to be a strong, intelligent woman and for teaching me how to weather my own adversities with grace. I cannot thank you enough for all the years of love and support. 


\section{Acknowledgements}

I would especially like to thank my advisor, Dr. David Horowitz, for taking on a thesis he didn't have to. Thank you for always being supportive and encouraging, especially when I felt like scraping the entire project. I would also like to thank my committee members, Dr. James Grehan, Dr. Tim Garrison, and Dr. José Padín, who brought enthusiasm and new insight into my project. Lastly, I would like to thank the cohort of women who patiently listened to my endless ramblings and constant worrying over drinks and tater tots. Without all of your encouragement and support, I might never have finished this project. Thank you for sharing your time, intelligence, and friendship over the years. 


\section{Table of Contents}

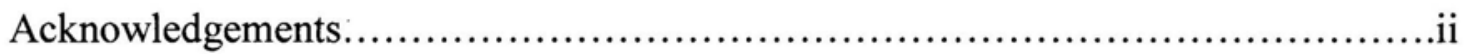

Introduction

New Orleans' Free Women of Color:

An Introduction.................................................................

Chapter One

A Natural Progression: Formation of a Community........................21

Chapter Two

Sui Generis: Myth and Reality of the Fabled Quadroon Balls................53

Chapter Three

"the objects of choice and affection."

Plaçage and Family....

Conclusion

"and they captivated all who were present."

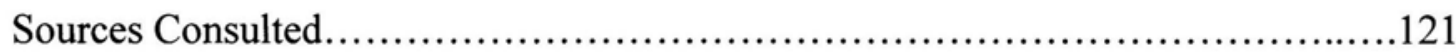




\section{New Orleans' Free Women of Color: An Introduction}

"nor did their faces wear an expression of Byronic despair... They walked erect, the smiled, and even laughed."

Visitors to Antebellum New Orleans rarely failed to comment on one of three things: the mud, the constant and varied gabble of international tongues, or the infamous slave market underneath the rotunda of the Saint Louis Hotel-the largest in North America. ${ }^{1}$ One spectacle above all, however, particularly captured their attention-the highly visible and wealthy class of free persons of color, specifically the females. The city and its fabled Quadroons sparked the imagination of men and women alike who found themselves alternately mesmerized and revolted by such blatant displays of sensuality and splendor. If the beauty of Helen of Troy launched a thousand ships, that of the New Orleans Quadroons created as many myths, yet for all the fascination the city and its inhabitant engendered, both have fallen victim to misrepresentation and misunderstanding.

The depiction of New Orleans as a city obsessed with sensual, corporal pleasure led many historians of Louisiana and North America to assume that it was an uneducated, backwater entrepôt with total disregard for intellectual pursuits. Even Thomas Jefferson furthered this presumption, noted historian Shannon Lee Dawdy, when he wrote " " $[\mathrm{n}]$ ot more than half of the inhabitants are supposed to be able to read

\footnotetext{
${ }^{1}$ For a comprehensive and intimate depiction of the infamous New Orleans slave market, see Walter Johnson, Soul by Soul, Life Inside the Antebellum Slave Market (Cambridge: Harvard University Press, 1999). As the largest slave market in North America, visitors from all across the country flocked to the market as much out of curiosity as for commerce. The first in depth exploration of the slave pens, Johnson's text offers not only insight into the horrors of chattel slavery, but into the structure of antebellum Southern society and culture.
} 
and write; of whom not more than 200, perhaps are able to do it well." ${ }^{2}$ Dawdy counters this falsification by pointing out that other scholars of education in Louisiana have discovered that in colonial Louisiana a significant portion of the citizens were interested in education and literacy, with the literacy rate comparable to ancien régime France as well as other Catholic communities of the era. ${ }^{3}$

Frequently referred to as the Babylon of Louisiana, New Orleans at first seems to be a charmingly European city but upon closer inspection it becomes less charming and more "foreign ... even uncivilized." Some believed, as visitor William Darby did, that "There are few places where human life can be enjoyed with more pleasure."4 Others, however, have been less charitable, focusing on the violence and libertinism of its citizens. Due to the disordered, chaotic nature of the development of New Orleans' culture, historians have frequently overlooked its importance and the larger historical significance of its Creole culture, relegating both the city and its inhabitants to the sidelines of history. The result is a grotesque caricature as the "Big Easy," a place where libidos and vice run free.

${ }^{2}$ Thomas Jefferson and William Dunbar, "Description of Louisiana," in Documents Relating to the Purchase and Exploration of Louisiana (Boston: Houghton Mifflin, 1904), 344; quoted in Shannon Lee Dawdy, Building the Devil's Empire: French Colonial New Orleans (Chicago: University of Chicago Press, 2008), 56.

${ }^{3}$ Dawdy, 56. Dawdy cogently argues that there were intellectuals in colonial Louisiana who closely followed Enlightenment ideologies, similar to their counterparts in France. For more on literacy and education in French colonial Louisiana see Martin Luther Riley, "The Development of Education in Louisiana prior to Statehood," Louisiana Historical Quarterly 19:3. (1936): 595-613; Stuart G. Noble and Arthur G. Nuhrah, "Education in Colonial Louisiana," Louisiana Historical Quarterly 32:4, (1949): 759-776.

\footnotetext{
${ }^{4}$ Dawdy, Building the Devil's Empire, xv.
} 
In October of 1845, Fanchon Morres sued John Compton for the amount of a promissory note endorsed by her deceased lover, Leonard B. Compton, in the amount of $\$ 5,000$. Representation for Fanchon argued that Leonard Compton previously endorsed the note over to John Compton with the intention of his transferring the funds to Fanchon upon his death. Due to the fact that Fanchon and Leonard never legally married, he had hoped to circumvent Louisiana jurisprudence concerning donatio mortis causa (donations upon death), thus transferring the funds to his partner via a trusted third party. In addition, Leonard willed one-fourth of his total estate to his and Fanchon's children, Scipio and Loretta. As fate would have it, Leonard misplaced his trust in John Compton, who virtually absconded with the note and refused to pay the funds to Fanchon claiming that as one of Leonard's legitimate heirs, he was entitled to the note and not she. The one-fourth, however, left to Scipio and Loretta remained unchallenged as he publicly acknowledged them as his natural children. Ultimately, the court found in favor of John Compton due to the fact that the endorsed note did not pass before a notary public and two witnesses, effectively eliminating any claim Fanchon may have had to the money. ${ }^{5}$

At first glance the case seems insignificant, reflecting an unfortunate turn of events. What makes the case remarkable, in the wider scope of American history, is the fact that Fanchon Morres was a free woman of color who lived in "open and notorious concubinage" with Leonard Compton, a white man. Fanchon bore Compton

\footnotetext{
${ }^{5}$ Fanchon Morres v John Compton, 12 Rob. 76 (Supreme Court of Louisiana, Western District, Alexandria, 1845).
} 
two children that he openly acknowledged as his own and treated them with great affection. The legal history of Louisiana is peppered with cases such as this one. The frequency with which free women of color took to the courts is surprising, as is the amount and detail of legal jurisprudence dedicated to the regulation of donations and gifts to femmes de couleur libre and natural children. ${ }^{6}$ Fanchon may not have won her suit; yet there are several examples of women who did so successfully although surprisingly little attention has been paid to such cases. The phenomenon of women of color using the courts, claiming inheritances, and openly challenging white relatives speaks to the freedom such women could exercise and the amount of selfdetermination they possessed.

In a society in which men set the social and sexual standards, the body of the Quadroon and the practice of plaçage (the formalized yet extralegal relationships between women of color and white men) offered a conundrum: one that questions race, gender, social, and cultural norms. Light but not white, the Quadroon was inextricably linked to the enslaved population; as a single, female head of household, she could own property, sue in court, and engage in commerce. Often as cultured as they were beautiful, the wealthier and more elite Quadroons incurred as many enemies

\footnotetext{
${ }^{6}$ The term natural children refers to children born in an extralegal relationship that the father openly acknowledges as his own, legitimizing their birth. When in reference to Louisiana, the term almost exclusively notes children of color, born of a mother of color and white father. Many European men had these children baptized in the Saint Louis Cathedral. According to research by historian Virginia Meacham Gould, between 1782 and 1791, 2,668 free women of color baptized their infants at the St. Louis Cathedral. Comparatively, only forty couples were recorded as legally married in that time period. In 1820, 352 free colored infants were baptized with only thirty-six recorded as legitimate. Regardless of legitimacy, Gould noted, a father's name frequently accompanied an entry; Virginia Meacham Gould, "In Full Enjoyment of Their Liberty: The Free Women of Color of the Gulf Ports of New Orleans, Mobile, and Pensacola, 1769-1800," (Ph.D.diss., Emory University, 1991), 321-323.
} 
as admirers. By one woman's estimation, who identified herself only as "Mother of a Family," the mulatto girls truly were "Heaven's last, worst gift to white men." What's more, she lamented, is that these girls threatened "the purity of the blood of the best families in Louisiana ... because so delicate and white has the mixture become, that it is absolutely introduced among the wives and daughters of the citizens." Grace King, historian and social commentator, echoed these sentiments by condemning the Quadroons, in reference to family (and racial) purity, domestic peace, and household dignity as "the most insidious and the deadliest foes a community ever possessed." Regardless of provoking such resentment, the Quadroons of Antebellum New Orleans received the most attention not from the pen of professional historians, but from that of the abolitionists. For the abolitionist crowd, the Quadroon provided the perfect case for their cause and quickly became the symbol for all the evils visited upon the oppressed race by their white masters. As victims of white lust for African women, mulatto children, abolitionists argued, were condemned to live a tragic life caught between two worlds, outcast from both. Light, but not entirely white, many Quadroons physically appeared similar enough for white audiences to sympathize with. Yet they bore the stigma of African heritage evinced through a slight discoloration of the crescent of the fingernail or a barely discernable curl to their otherwise straight hair. Like many of their real life counterparts, the abolitionist's

\footnotetext{
${ }^{7}$ Niles Weekly Register, November 5, 1825, Baltimore, citing the New Orleans Gazette; Grace King, New Orleans, the Place and the People (New York: Macmillan \& Co., 1895), 348.
} 
Quadroon was beautiful, chaste, and pious, marred only by the socially repugnant practice of miscegenation.

The concept and theme of the tragic mulatto grew to such proportions that it rarely failed to infiltrate studies of the free population of color, resulting in an inherent victimization. Travel writers and visitors to Southeastern Louisiana wrote with an almost schizophrenic tendency remarking on the beauty and propriety of the population followed by condemnations of it as sinful and the product of unnatural couplings. Considering the dearth of primary sources such as memoirs or journals written by Quadroon women, historians of Louisiana must use such travel writings, albeit carefully and with a healthy dose of skepticism. Largely disregarding the industry and vibrancy of the community, contemporary scholars, professional and amateur alike, continued to promote the concept of a ritualized victimization of an entire population of people while at the same time condemning them for perceived moral laxity. As the product of miscegenation, the gens de couleur libre could be nothing either than the offspring of victimized or promiscuous women and lecherous white masters. It is little wonder that subsequent generations of historians failed to distinguish the experiences of free women of color from enslaved black women. ${ }^{8}$

${ }^{8}$ Contemporary novels and observations that misrepresented the lives of free women include George Washington Cable, The Creoles of Louisiana (New York: Charles Scribner's Sons, 1901); George Washington Cable, The Grandissimes (New York: Charles Scribner's Sons, 1880); George Washington Cable, "Tite Poulette," in Old Creole Days (New York Charles Scribner's Sons 1893); Grace King, New Orleans (New York: Macmillan \& Co., 1895); Grace King, Creole Families of New Orleans (New York: Macmillan \& Co., 1921); Harriet Martineau, Society in America in Three Volumes (London: Saunders and Otley, 1837); Frederick Law Olmstead, A Journey in the Seaboard Slave States 2 vols (New York, 1904). Modern texts include Ira Berlin, Slaves Without Masters The Free Negro in the Antebellum South (New York: New York University Press, 1978); John Blassingame, Black New 
Late-nineteenth century novels and short stories such as the prolific novelist George Washington Cable's "Tite Poulette," Madame Delphine, and The Grandissimes shined a very unflattering spotlight on the activities of the French Creoles of Louisiana, a population Cable openly loathed. Perhaps not so coincidentally, Cable became quite popular with Northern audiences and reviled by the Creoles. Madame Delphine, in particular, offered scathing commentary on the colored and white Creole communities. In the novel, Madame Delphine's daughter falls in love with a white suitor she can never legally wed. Delphine must come to grips with her past and the world in which she lives. Delphine, as the tragic figure in the novel, denies her relationship with her daughter in order to prove her daughter's whiteness, thus allowing her to marry into white society. In the end, Delphine dies, but not before she sees her daughter married into the white community, clearly fulfilling her greatest wish in the world. Cable portrayed all of his Quadroons as dignified, yet ultimately tragic, victims of the Southern establishment.

In 1916, Alice Dunbar-Nelson, a Creole of color herself, published a two-part article in the Journal of Negro History titled "People of Color in Louisiana," one of the first academic pieces to explore the free community of color as an independent and separate community. "The glory and shame of the city were her Quadroons and octoroons," she wrote. Dunbar-Nelson started by chronicling the development of the

Orleans, 1860-1880 (Chicago: University of Chicago Press, 1973); Eugene Genovese, Roll, Jordan, Roll: The World the Slaves Made (New York: Pantheon Books, 1974); Herbert Gutman, The Black Family in Slavery and Freedom, 1750-1925 (New York: Vintage, 1976); Walter Johnson, Soul by Soul: Life Inside the Antebellum Slave Market (Cambridge, Mass.: Harvard University Press, 1999) are all excellent examinations of the free and enslaved black population of the Antebellum South yet they all place free women of color in the role of victim or at best, as passive. 
community and the caste system in Louisiana, following the population up to Reconstruction. Despite the early date of publication and being denied access to the necessary archives due to her race, these articles provide some of the best leads and insight into early Creole history. Yet her examination of free women of color remained limited and did little to further understanding of their social or cultural contribution. "Writers on fire with the romance of this continental city love to speak of the splendors of the French Opera House ... and tell of the tiers of beautiful women with their jewels and airs and graces," she wrote. "Above the orchestra ... were four tiers. . the second filled with a second array of beautiful women, attired like those of the first, with no apparent difference; yet these were the octoroons and Quadroons whose beauty and wealth were all the passports needed." ${ }^{\prime 9}$ Subsequent works focusing on Louisiana, and specifically New Orleans, drew attention to the free women of color in a similar manner, almost exclusively fixating on their ethereal beauty and their eerie similarity to, but exclusion from, the white community.

\section{Published in 1938, The French Quarter: An Informal History of the New}

Orleans Underworld, by amateur historian Herbert Asbury, quickly became a popular and widely read history of the city. Asbury's text, while certainly an entertaining and easy read, furthered the one-dimensional character of the city's femmes de couleur libre and encouraged the myth of New Orleans as a Southern Sodom. The Quadroons were "notorious for the elegance of their raiment, their silks and satins, their plumes

\footnotetext{
${ }^{9}$ Alice Dunbar-Nelson, "People of Color in Louisiana, Part II," Journal of Negro History 2:1
} (Jan. 1917), 62. 
and jewelry," he wrote, they possessed "beauty and arrogance," resulting in attracting the venomous ire of the authorities. Asbury elaborates on the physical and material aspects of the women but does little to commend other attributes, leaving the casual reader with the distinct impression that Quadroons were little more than ornaments collected by wealthy white Creoles. From start to finish, Asbury brought the debauched culture and chaotic development theory of New Orleans to a new generation. $^{10}$

In 1952, the historian Donald Everett submitted his dissertation "Free Persons of Color in New Orleans, 1803-1865." This groundbreaking work provided one of the best historical examinations of the free population in the modern era. Everett's capable study incorporated many excerpts from travel journals but also court and census records. Everett recognized the role of free women of color in New Orleans' economy and the preference white men showed for femmes de couleur libre. In doing so, he acknowledged the benefits of plaçage as well as the vulnerability of the women involved without condemning them to the role of victim or whore. Despite his lengthy, well-informed treatment of the free population, however, Everett only briefly

10 "Désordre (disorder) was a world used with increasing frequency in the ancien régime, indexing an Enlightenment-era desire to classify, organize, and rationalize the natural world, to order society, and to discipline the individual. The Dictionnaire de l'Acadmie française of 1798 offered six definitions of désordre: (1) disarray of things without rank and organization; (2) disarray of the moral order; (3) depravity of a person; (4) confusion of the mind; (5) pillage and havoc; and (6) unexpected dissension in a group." "The public image of New Orleans in the French period seemed to reflect all these forms of disorder. Under the influence of the "disorder" vocabulary embedded in the archive, the historians of Louisiana have used a language of disorder, misrule, and failure to describe the colony's social, political, and economic conditions." Dawdy, Building the Devil's Empire, 29. 
discusses plaçage and barely scratches the surface concerning the nature and role of the free women of color.

The Quadroons of New Orleans continued to suffer from neglect and misrepresentation in twentieth-century accounts. Historians of slavery and southern black women, for example, have written at length on the sexual experiences of black women and white men. Most of the research, however, centers on the institutionalized rape, victimization, and exploitation of black women at the hands of white males. In the American Atlantic, children of these encounters usually followed their mothers into slavery, but in New Orleans many were freed. With the rise in popularity of black studies, historians began addressing the role of the free African American with a primary emphasis on liberated black slaves and concepts of racial determination, designation, and the phenomena of passing into white society. Yet sources stayed relatively silent on free women of color who engaged in relationships with elite white Creole men.

Even late into the twentieth century, scholars largely failed to distinguish the experiences of free women of color from those of enslaved women with little nuance in regard to economic, educational, and cultural differences. All women of colorwhether free or enslaved - continued to be viewed through the lens of slavery. Studies that examine free women of color were very rare and those focusing exclusively on them were virtually nonexistent. As a result, the actual experiences of free women of color in the Gulf States passed unnoticed for generations. In the event that these women were mentioned at all, it was normally within the context of the fabled 
Quadroon balls and as the mistresses of white men, subsequently resulting in a onedimensional character that lived expressly for the enjoyment of white males. This work does not assume that the experiences of free women of color were the same as those of their enslaved counterparts. Free women of color existed in a separate, unique world - in a community precariously balanced between free whites and enslaved blacks. This does not preclude exploitation by the white ruling class, but it does include one very crucial difference: free women of color identified as and called themselves free.

Seeking to fill this gap, historian Virginia Meacham Gould offered her dissertation "In Full Enjoyment of Their Liberty: The Free Women of Color of the Gulf Ports of New Orleans, Mobile, and Pensacola, 1769-1860," in 1991. Gould's research discovers the lives and identities of free women in the Gulf South-with the primary focus on the common free population. Perhaps most importantly, Gould discovered a treasure-trove of family letters left by several women of color. These letters, subsequently published as Chained to the Rock of Adversity, published in 1996, focused on the day-to-day activities of these women and the centrality of the home and family in their lives. Gould only briefly discusses the elite women of color-the fabled Quadroons of the Orleans Ballroom-however, she does acknowledge the role plaçage played in the creation and wealth of the free community. Both the dissertation and text are invaluable for their contribution to the knowledge about free women of color, specifically in the port cities of the Gulf South, yet are somewhat lacking in an emphasis upon the agency employed by women who contracted plaçage relationships. 
Due to the silence of their own voices, approaching the topic of New Orleans' Quadroons at length is difficult at best. Few scholars, until quite recently, even attempted to discern the experiences of free women of color from those of their enslaved black sisters, consequently resulting in both the perpetuation of a myth and the disregard of an entire population. For far too long the concept of the tragic mulatto and associated moral biases continued to pervade the historical record. The Creole community of color received very little attention and in many ways was treated as the bastard offspring of the white and black communities.

Building upon the groundwork laid by Meacham Gould, this thesis attempts to examine a more specific portion of the population, to examine the lives of the elite Quadroons of Louisiana - the women who were raised as "tenderly and carefully brought up as any white girl," and their influence upon a city that has been much neglected by American historians. ${ }^{11}$ It is my hope that this thesis can focus on the percentage of the population that carried the brunt of the misrepresentation: those known as placeés or direct decedents of-and offer a more realistic interpretation of their lives and choices. It is my contention that by using the sources that do remainproperty records, legal documents, census records, travel journals, comparative studies, and other remaining literature--it is possible to construct a profile of threedimensional, dynamic historical figures who deserve to be recognized for their role in shaping the Antebellum South and fostering a vibrant, intellectual community within unique and oppressive circumstances.

\footnotetext{
${ }^{11}$ Eleanor Early, New Orleans Holiday (New York: Rinehart \& Company, Inc., 1947), 193.
} 
I offer this thesis as a renewal in the conversation concerning the role of free women of color and how these women actively shaped their lives, demonstrating that the formation of this free population of color was very much a natural progressionnot simply the disgraceful byproduct of chattel slavery. To fully reconstruct the identity and to understand the ramifications of the world which they created for themselves would require a more deeply researched project combining several fields of inquiry including, but not limited to, race, gender, and culture. I hope to as least begin to understand how these women, who were neither black nor white, constructed lives within the oppressive hierarchy of the Gulf South, specifically in Louisiana.

Finding a new lens with which to view Creole women of color requires a little imagination and speculation. They are a group of women central to a unique community who yet remain largely elusive. Regardless of their relative personal silence, nevertheless, it is important to attempt an accurate reconstruction of this population whose legacy remains in the modern era. Forbidden the legal sanctity of marriage to those not of their own caste, many Creole women of color raised families, educated children, ran successful business enterprises, and persevered over the abject adversity of a chattel slavery society. Forced to create a life within the strict confines of a slave society, plaçage offered a means of betterment and social mobility.

To fully understand the nature, system, and allure of plaçage, it is imperative to place the system not just within the wider context of the American South, but also within a wider pan-Atlantic perspective. Louisiana, long at the crossroads of transatlantic and pan-Caribbean trade routes, has always been connected to a wider, 
global culture. Consequently, the people of Louisiana have always grappled with a complex, dynamic identity influenced by African, Caribbean, Franco, Latin, and Anglo cultures. This peculiar interplay of ethnicities and traditions left their mark in the form of the colorful Creole culture and the formation of an enduring community spearheaded and closely guarded by colored women in a world dominated by white men. ${ }^{12}$ Viewed within the context of American history, New Orleans and its curious inhabitants appear exotic and unique; however, when viewed within an Atlantic framework, New Orleans becomes illustrative of, not exceptional to, colonies of the larger Atlantic world.

Due to the scarcity of primary sources concerning the lives of free women of color this thesis will, at times, expand the discussion of Quadroon and libre women outside the confines of New Orleans. It will, however, primarily focus upon the city and its immediate environs. Also, as the voices of the women themselves remain largely silent-in the form of memoirs, letters, and the like — the following is largely speculative and a reconstruction based on legal records, local histories, and the recollections of observers--both by locals and outsiders. Through the use of a variety of sources and by viewing the culture through the lens of Atlantic history it is possible

\footnotetext{
${ }^{12}$ Studies of Creole Louisiana include: Ira Berlin, "From Creole to African: Atlantic Creoles and the Origins of African-American Society in Mainland North America," William and Mary Quarterly 53:2 (April 1996): 251-288; David Buisseret and Steven G. Reinhardt, eds., Creolization in the Americas (College Station: Texas A \& M University Press, 2000); Glen Conrad, ed. Readings in Louisiana History (New Orleans: Louisiana Historical Association, 1978); Gwendolyn Midlo Hall, Africans in Colonial Louisiana: The Development of Afro-Creole Culture in the Eighteenth Century (Baton Rouge: Louisiana State University Press, 1992); Sybil Kein, ed. Creole: the History and Legacy of Louisiana's Free People of Color (Baton Rouge: Louisiana State University Press, 2000); Joseph Logsdon and Arnold Hirsh, eds., Creole New Orleans: Race and Americanization (Baton Rouge: Louisiana State University Press, 1992).
} 
to reconstruct the myriad of ways these women identified and better understand the choices they made. Central to this identity was a French heritage, family, and selfdetermination as women, mothers, lovers, and as legally free individuals. The French ethos created room for a third caste of individuals and since the earliest days of the colony, free people of color numbered among the populace. It was with the arrival of the Spanish, however, and their unique set of socially and morally acceptable practices that the number of free people of color greatly, and rapidly, expanded. Indeed, the Spanish influence loosened the strict laws governing the manumission of slaves, effectively encouraging the liberation of lovers and children.

Chapter One examines the deep entrenchment of the French and, to a lesser degree, Spanish ethos in Louisiana and their influence upon the region's practices, traditions, values, and culture. Despite the relatively short tenure of French colonial rule, it is this culture that the inhabitants of Louisiana, New Orleanians in particular, vehemently clung to. With the arrival of the Spanish, the colonists refused to abandon their French connections and language and continued to live as though they were indeed French subjects. The Spanish, however, shared a Latin heritage with the French, reinforcing many of the existing traditions despite continued resistance to the Spanish presence. Regardless of the colonists' stubborn loyalty to France, they did, however, adapt certain aspects of Spanish culture. In particular, the Spanish practice of coartación (self-purchase by slaves) profoundly affected the nature and shade of Louisiana's population. With the arrival of the American forces and the Louisiana 
Purchase, the former French and Spanish subjects shunned all things American, continuing their European ways.

The French Creoles' love of dance, the French language, and observation of Catholic holidays brazenly defied all attempts of Americanization and in many ways served to Gallicize the Americans. Chapter Two examines the phenomena known as the Quadroon Balls-dances that became so mythologized in New Orleans' history that stories still persist of the decadent affairs and the women who attended. The dances became a meeting ground for free women of color and Anglo-European men, prompting many to condemn them as fancy auction blocks where mothers sold their daughters to the highest bidder. In this chapter I attempt to discern fact from fiction and to understand the role of the dances and the formation of plaçage relationships.

Chapter Three will address the nature of plaçage relationships and the centrality of family in the lives of New Orleans' Quadroons. Contemporaries, critics, and many historians equated the formalized interracial relationships to prostitution and promulgated the concept that the women involved were powerless victims, following in their mothers' footsteps into sexual slavery. In response, this chapter will examine various cases of plaçage through the lens of legal records in an attempt to demonstrate the self-determination and freedom exercised by the Quadroon women involved. This chapter also comments on the phenomena of passing and how the larger Creole community felt about women who attempted to do so. ${ }^{13}$

\footnotetext{
${ }^{13}$ Dawdy explains that passing in colonial Louisiana was very difficult because "French colonial New Orleans was what anthropologists call a "face to face" community, meaning that
} 
In many ways, New Orleans is a city built on myths and fabrications-many of which still persist in the twenty-first century. This city of "Incredible laxity of morals," and its Quadroons beg to be understood not only within an Atlantic context, but also within the wider scope of American history—not as a unique, curiosity but as an integral part of the country as a whole. Louisiana, wrote historian Gwendolyn Midlo Hall, may have left behind a tradition of official corruption and defiance of authority; however, it also passed on a tradition of racial openness that has never been altogether repressed. More importantly, Louisiana is (along with New York) the "most significant source of Africanization of the entire culture of the United States." ${ }^{14}$ A collective examination of New Orleans' culture and people helps to expand our understanding not only of colonialism and the development of Creole cultures, but the ability of a group of women to rise above an oppressive and gendered social structure to create rich, compelling identities and contributions to their community.

permanent residents probably recognized each other on the streets and could quickly place one another within family trees and social geographies." I think the same can be said of the Spanish and early American periods as well. Dawdy, 23.

${ }^{14}$ Alexis De Tocqueville, Journey to America, ed. J.P.Mayer,, trans. George Lawrence (Westport, Conn.:Greenwood, 1981), 165; Gwendolyn Midlo Hall, Africans In Louisiana, 157. 
In reference to people of color, the term "Negro," is almost exclusively

reserved for reference to those who were either currently or had at one point, been

enslaved. The term libre or gens de couleur libre noted those individuals who had

never known slavery. The term Creole has many meanings and has transformed over

the course of its history in North America. An official definition offered by the

Harvard Encyclopedia of American Ethnic Groups reads:

Louisianians of French and Spanish descent began referring to themselves as Creoles following the Louisiana Purchase (1803) in order to distinguish themselves from the Anglo-Americans who started to move into Louisiana at this time. The indigenous whites adopted the term, insisting, most unhistorically, that it be applied exclusively to them. The life of this dying group is depicted in George Washington Cable's Ole Creole Days (1879) and in some of the works of Lafcadio Hearn.

In the United States, in the $20^{\text {th }}$ century, Creole most often refers to the Louisiana Creoles of color. Ranging in appearance from mulattos to northern European whites, the Creoles of color constitute a Caribbean phenomenon in the United States. The product of miscegenation in a seigneurial society, they achieved elite status in Louisiana, and in the early $19^{\text {th }}$ century some were slaveholders. Many, educated in France, were patrons of the opera and of literary societies. A description of their lives is provided by Alice DunbarNelson in the Alice Dunbar Nelson Reader (1979) and Rodolphe Lucien Desdune's Nos homes et notre histoire (1911, English translation, 1978). Francis J. Woods tells the life story of one extended family in Marginality and Identity: A Colored Creole Family Through Ten Generations (1972).

Louisiana Creoles of color thus constitute a self-conscious group, who are perceived in their locale as different and separate. They live in New Orleans and in a number of other bayou towns. Historically they have been endogamous, and until late in the $19^{\text {th }}$ century spoke mostly French. Perhaps the best-known Creole of color is the jazz musician Jelly Roll Morton, whose own social status must have been marginalized in Creole society. Overwhelmingly Catholic, the New Orleans Creoles usually attended parochial schools; Xavier University is closely associated with them. Their ethnicity is exceedingly difficult to maintain outside the New Orleans area. Over time, a great many have passed into white groups in other parts of the country, and others have become integrated as 
blacks. This latter choice is not based wholly on appearance, for many Creoles who choose to identify as Afro-Americans are white in appearance. ${ }^{15}$

According to historian Virginia Dominguez, the term Creole carries with it an innate connotation of historical and social economic status, and a sense of identity and belonging to a selective group of individuals. ${ }^{16}$ Gwendolyn Midlo Hall, considered by many to be the foremost historian of African Louisiana, explains that the word Creole refers exclusively to the people and culture of lower Louisiana. This is the definition that I employ throughout this thesis. I use the term Creole to denote one's heritage, location, and self-identification with the larger Louisiana landscape. A Creole can be black, white, or something in between with a blend of French, Spanish, African, Caribbean, and even Native American ancestry.

Another term that requires clarification is 'Quadroon.' The original use of the term referred to an individual with one-quarter Negro blood and served as an ethnic marker in legal documents. The term, however, rapidly became associated with images of illicit sex and seductresses of African descent. The term lost much of its original meaning as it became inextricably linked to the free women of color whom cohabitated with white men. Now both racially and sexually marked, the term almost exclusively referred to the female body, and came to include women of varying degrees of African blood.

${ }^{15}$ Stephen Thernstrom, ed., Harvard Encyclopedia of American Ethnic Groups (Cambridge, Mass.: Belknap Press of Harvard University, 1980), 247.

${ }^{16}$ Virginia Domínguez, White by Definition: Social Classification in Creole Louisiana (New Brunswick, N.J.: Rutgers University Press, 1986), 263. 
Due to the varying dedication and honesty of the clerics and notaries who recorded the racial designations of New Orleans' citizens, it is difficult to ascertain the specific racial heritage of the women discussed in this thesis. Money placed in the right palm could negate the required designation of f.m.c. or f.w.c. (free man of color or free woman of color) in legal or baptismal records. The term Quadroon, therefore, is used interchangeably with femmes de couleur libre and free women of color; it denotes a female of varying, yet minimal, African heritage. The common thread, nevertheless, is the self-identification as a Creole of color with primarily a European heritage. 


\section{Chapter One: \\ A Natural Progression: Formation of a Community}

"Send women. My men are chasing Indian wenches in the woods." ${ }^{17}$ Sensing a potential crisis, the leading colonial administrator Sieur Jean Baptiste Le Moyne Bienville petitioned the French government for help. His rag-tag band of Frenchmen endured starvation, disease, and fatigue, but apparently refused to endure celibacy for lack of proper Frenchwomen. It would have been more appropriate for Bienville to ask for whores, thieves, and women of ill repute, for that is exactly what he got. Few Frenchmen, or women, of any standing could be enticed to leave France for the harsh wilderness of the failing colony in the New World. As a last ditch effort, the colonial authorities scoured the prisons and streets of France looking for viable candidates to ship off to Louisiana.

The issue of Franco-Indian miscegenation plagued the frontier society of New France and baffled the colonial authorities. How could the crown establish a colony in New France, populate it with families, and solidify their presence in North America? The crown concluded that the budding colony needed French women who would assist in raising the families necessary to populate the region, but first the men must be enticed away from their Indian consorts. The Frenchmen, authorities reasoned, would almost certainly prefer white women to native women; only out of necessity did the frontiersmen take Indian lovers. Historians have also used similar reasoning to explain

${ }^{17}$ Antoine Le Page du Pratz, The History of Louisiana, or of the Western Parts of Virginia and Carolina: Containing a Description of the Countries that Lie on Both Sides of the River Mississippi: with an Account of the Settlements, Inhabitants, Soil, Climate, and Products (London: T. Becket, 1774), 306-307. 
the prevalence of white-black miscegenation, arguing that white men had to overcome some innate aversion to women of darker skin color in order to satisfy their basest need. Furthermore, this penchant for miscegenation has been explained as fetishism and habitually portrays the women as a simpleton, or a victim. It is this notion that drives the misconception that all women of color who engage in sexual relationships with white men did so out of coercion or force. It excluded the possibility that the Francophile males just may have been naturally attracted to these women and additionally the women might have brought benefits of their own such as social connections and trade networks.

From the beginning, the French crown struggled to establish a population and suitable leadership in Louisiana. No one wanted the increasing financial burden that Louisiana rapidly became, nor did many willingly choose to immigrate to Louisiana. With the crown on the brink of bankruptcy, the powerful King Louis XIV dead, and his grandson, Louis XV yet to reach adulthood, Louis XIV's brother the Duke of Orleans turned to Scottish financier John Law. Law, he hoped, would solve the financial difficulties of France, salvage the dignity of the royal family, and save the colony from ruin. Law concerned himself with investments and banking, leaving the day-to-day management of Louisiana to his subordinate, Bienville. Law, still responsible for populating the colony, scoured the dark corners of France in order to meet the established quota of bodies to be sent to Louisiana. Law's employees "spared no violence in kidnapping city scourings [sic] and unsophisticated peasants." They shanghaied all "Vagrants, beggars, disorderly soldiers, galley-slaves, gipsies [sic], 
paupers, prostitutes, political suspects, black sheep of good families, felons," onto ships and exiled them to the ends of the earth: Louisiana. ${ }^{18}$

In September of 1719, 180 women marched into the Church of Saint-Martindes-Champs to be forcibly married to men chosen from a group of felonious males, also destined for the French colony. ${ }^{19}$ Another shipment of "corrections girls" (as these girls became known) set sail in 1721. According to the colonial governor, "Several were given to sailors who asked insistently for them; they could scarcely have been married off to good residents as these girls were not well selected." ${ }^{20}$ To entice the "good" citizens of Louisiana to lower their standards and take a wife from the remaining, less attractive women, the government offered free land, houses, and permanent residency in the colony. Despite various incentives to settle down and reproduce with white women, many of the French colonists continued to take Indian consorts, several of them actually participating in marriage ceremonies, further

${ }^{18}$ Walter Hart Blumenthal, Brides from Bridewell: Female Felons Sent to Colonial America (Rutland, VT: Charles E. Tuttle Co., Inc., 1962), 79. For more on the early settlement of French Louisiana see Bradley G. Bond, ed., French Colonial Louisiana and the Atlantic World (Baton Rouge: Louisiana State University Press, 2005) ; Glen R. Conrad, "Reluctant Imperialist: France in North America," in La Salle and His Legacy: Frenchmen and Indians in the Lower Mississippi Valley, ed. Patricia Kay Galloway (Jackson: University Press of Mississippi, 1995), 93-105; Glen R. Conrad, ed., The French Experience in Louisiana (Lafayette: University of Southwestern Louisiana, 1995) ; William Eccles, "French Aims and Means in Colonial North America," in France and North America: Three Hundred Years of Dialogue, ed., Mathé Allain and Glenn R. Conrad (Lafayette:University of Southwestern Louisiana, 1973); and Thomas N. Ingersoll, Mammon and Manon in Early New Orleans: The First Slave Society in the Deep South, 1718-1819 (Knoxville: University of Tennessee Press, 1999).

${ }^{19}$ Blumenthal, Brides from Bridewell, 81.

${ }^{20}$ Harnett Kane, Queen New Orleans City by the River (1949); in Monique Guillory "Some Enchanted Evening on the Auction Block: The Cultural Legacy of the New Orleans Quadroon Balls," (Ph.D. diss., New York University, 1999), 108. 
maddening the French crown. The practice of forced immigration largely ceased after 1719, due in part to popular dissent in France, but a more likely reason was not the arrival of more white women but the increase in importation of African slaves.

In one last attempt at boosting the female population, France supposedly sent a group of "worthy women," in 1728 and another in 1751, chosen by the French bishop himself, from reputable, middle class families. ${ }^{21}$ These women arrived in Louisiana with their trousseau in company-issued trunks and thus became known and continue to be known as the filles a la cassette, or casket girls, in reference to the trunks. Both the nuns and armed guards carefully guarded the women at the Ursuline convent, with local men only permitted to call during the day. When only one woman remained, a wild frenzy ensued despite her being "anything but pretty, having the air of a guardsman than of a girl," with two men engaging in a violent dispute for her hand. For many generations men and women fought over the blood lines of the filles a la cassette; the oldest families of New Orleans all claimed descent from the casket girls and deny any connection to those of the convict girls. ${ }^{22}$ Claiming a filles a la cassette

${ }^{21}$ Guillory, "Some Enchanted Evening," 110.

${ }^{22}$ Guillory, "Some Enchanted Evening," 112. The Catholic Church has a long history in Louisiana, dating back to the very first European settlers and trappers. Among the first religious ambassadors to make their home in French colonial Louisiana were the Ursuline nuns, a particularly devout sect of women who established and maintained their own houses of worship and welfare. The nuns are illustrative of the strong, independent female presence in the colony. For more on the Ursuline nuns and their activities in Louisiana, see Caryn Cossé Bell, "French Religious Culture in Afro-Creole New Orleans, 1718-1877," U.S. Catholic Historian 17:2 (Spring 1999), 1-16; Emily Clark, Masterless Mistresses, The New Orleans Ursulines and the Development of a New World Society 1727-1834 (Chapel Hill: University of North Carolina Press, 2007). In addition to the French Ursulines, an order of nuns comprised solely of free women of color developed to serve the needs of the free colored community. The daughter of a placeé and white father, Sister Henriette Delille founded the Sisters of the Holy Family. For more on Delille and the Sisters see Sister Audrey Marie Detiege, Henriette 
became a mark of respectability and propriety so much so that historian Herbert

Asbury wrote:

By some queer physiological mischance none of the correction girls, apparently, ever bore a child. On the other hand, the casket girls would seem to have been extraordinarily fertile, each becoming the mother of at least a hundred children, who in turn were likewise blessed with enormous families. Proof of these biological miracles is furnished by the fact that practically every native family of Louisiana is able to trace its descent in an unbroken line from one of the filles a la cassette. $^{23}$

Leading Louisiana historian Carl Brasseaux explains that despite the debauched reputation of many of the French female imports, their presence caused a ripple throughout lower Louisiana. Soon after their arrival, Indian concubinage ceased to be much of a concern for local administration, but this is not to say that all white men gave up their Indian concubines. In the frontier posts and other remote locations many Frenchmen retained their Indian consorts, but in the more urban areas, such as New Orleans, African women quickly and effectively superseded Indian. ${ }^{24}$ The earliest interracial relationships involved French-Canadian courrers $d u$ bois and Indian women, but there had also been a few free blacks arriving from the West Indies or as

Delille: Free Woman of Color (New Orleans: Sisters of the Holy Family, 1976) ; Cyprian Davis, OSB, Henriette Delille: Servant of Slaves, Witness to the Poor (New Orleans: Archdiocese of New Orleans in cooperation with the Sisters of the Holy Family, 2004) ; Tracy Fessenden, "The Sisters of the Holy Family and the Veil of Race," Religion and American Culture 10:2 (Summer 2000), 187-224.

${ }^{23}$ Herbert Asbury, The French Quarter: An Informal History of the New Orleans Underworld (New York: Thunder's Mouth Press, 1936), 9. Many suspect that the casket girls are a myth, and that in fact, they are an invention by the Creole aristocracy meant to distance themselves from the demimonde. Blumenthal suggests that the shipment of correction girls, dated 1721/1722, is in fact one and the same as the shipment of casket girls, as recorded by the Louisiana historian Charles Gayarré. See Blumenthal, 96.

${ }^{24}$ Carl Brasseaux, "The Moral Climate of French Colonial Louisiana, 1699-1763," in Louisiana History: The Journal of the Louisiana Historical Society 27:1 (Winter 1986) : 32. 
servants, not the slaves of, wealthier French transplants. French/African miscegenation was not unheard of, nonetheless, with the introduction of African slaves, the population of gens de couleur took on a new shade and expanded in numbers as EuroAnglo men turned from Indian concubines to black slave women. By 1763, a notable mulatto population emerged and started to thrive: early census records report at least 187 mulattoes living in the colony. ${ }^{25}$

Many religious and secular leaders in Louisiana tolerated these interracial relationships not because of the lack of suitable white females but, writes Carl Brasseaux, because they were often as dissolute as their flock. Father St. Cosme, a priest of the colony, reportedly fathered a child, while Father Beaubois attempted to seduce the governor's French-born domestic servant while he was administering confession! ${ }^{26}$ Louisiana equated, to most clergy, exile from the opulent, warm glow of Parisian society but also a world away from papal authority. Few ventured away from their domiciles, leaving those outside urban center without religious guidance or interference. This, Brasseaux explains, resulted in an a la carte approach to Catholicism and a rather indifferent religious community. The prevalence of gambling, public drunkenness, and sexual promiscuity that became a hallmark of colonial Louisiana persisted well into the modern era, demonstrating the pervasiveness

${ }^{25}$ Jacqueline K. Voorhies, comp., Some Late Eighteenth-Century Louisianians: Census Records of the Colony, 1758-1796 (Lafayette, La: University of Southwest Louisiana, 1973), 103.

${ }^{26}$ Brasseaux, "The Moral Climate," 34. 
of the frontier mentality in Louisiana's Creole culture. This deep-seated independence and moral laxity may help to explain such a large mulatto population.

It is important to remember that Louisiana was situated in a wider, Frenchcontrolled arch of outposts that stretched from Quebec along the Saint Lawrence River, through what is now known as the Great Lakes Region, and along the various tributaries of the Ohio, Illinois, and Wisconsin Rivers, then down to New Orleans along the Mississippi. Following the arch further a field, it extended to the west coat of Africa and along the sugar colonies of the Caribbean. The French crown had a long history of interaction and intimacy with Africans and other non-European peoples. It is, therefore, not only helpful but also necessary to approach the history of New Orleans through the traditions, customs, and languages of other cultures. The French colonial island of Saint Domingue provides a window of insight into French attitudes and practices blended with Caribbean traditions that influenced Louisiana, and more specifically, New Orleans.

Interracial liaisons, whether forced or consensual, continued to flourish, as did the free population of color. Louisiana historian Gwendolyn Midlo Hall demonstrated through extensive research that these open patterns of gender and race relations in Louisiana could not simply be the result of degenerate Frenchmen, but carried over from the French experience in Senegal. In Senegal, Hall explains, French officials and workers became extremely dependent on Wolof women who provided not only food and medical aid but also companionship. These officials "testified to the beauty, intelligence, and remarkable adaptability of Wolof women." French men in Senegal 
particularly admired these Wolof women for their "lustrous, very dark skins, and their elegant dress." Wealthy and influential Wolof women, who were involved with and had connections to, the Senegal trade networks, found themselves highly sought after by French officials and workers stationed in Senegal. Via relationships with these women and their kinsmen, Europeans sought to accumulate wealth through these connections as well as securing a competent caretaker in the event of a bout of frequent malarial or tropical illness that habitually devastated Europeans in West Africa. As a result of these relationships a wealthy and influential Euro-African community developed in Senegal, similar to that which would develop in New Orleans and Saint Domingue. ${ }^{27}$

The prevalent French ethos greatly impacted the interracial liaisons and interactions of the young colony. According to Guillaume, the French concept of ethnicity was cultural and not strictly racial, with an emphasis on religious affiliation. Furthermore, King Louis XIII only allowed the enslavement and deportation of Africans to the French Caribbean after being persuaded that that was the only way to convert them to Catholicism. ${ }^{28}$ For the French, it seems, skin color was not the

${ }^{27}$ Gwendolyn Midlo Hall, "African Women in French and Spanish Louisiana Origins, Roles, Family, Work, Treatment," in The Devil's Lane Sex and Race in The Early South, Catherine Clinton and Michele Gillespie, eds., (Oxford: Oxford University Press, 1997), 249. Hall has compiled an exhaustive slave and free black database that tracks the importation, sale, and movement of thousands of slaves throughout Louisiana. The summation of Hall's research on the slave and free populations of Louisiana can be viewed at www.ibibio.org/laslave. Her research demonstrated the role of various African tribes in the Africanization and Creolization of Louisiana and by her estimation, the United States.

${ }^{28}$ Guillaume Aubert, "“The Blood of France:” Race and Purity of Blood in the French Atlantic World," The William and Mary Quarterly 61:3 (July 2004), 12. 
defining characteristic that set them apart from 'civilized' people. It was not until 1778 that the French authorities officially forbade interracial marriages, so it seems that the relative acceptance of miscegenation among French citizens contributed to the prevalence of occurrence in the North American and Caribbean colonies. Prior to 1778, Louisiana historian Gary B. Mills explains, French citizens of African ancestry were often considered exotic; furthermore, Mills reports, at one point King Louis XIV allegedly kept his own mistress of color. ${ }^{29}$ Whether or not this is a verifiable fact, we do know that after the French Revolution, citizenship was restored for all French-born men and women, regardless of color. French citizenship could not erase all hostilities or resentment between the two races; however, it did discourage the blatant, outright disenfranchisement of those of African ethnicity like that that developed in North America. $^{30}$

The French sugar colonies provide the perfect comparative society to that of New Orleans, owing to its large free, mixed, and enslaved populations. ${ }^{31}$ In the French

${ }^{29}$ Gary B. Mills, The Forgotten People: Cane River's Creoles of Color (Baton Rouge: Louisiana State University Press, 1977), 17.

${ }^{30}$ For more on the success of free men of color abroad see Michel Fabre, "New Orleans Expatriates in France: Romance and Reality," in Creole: the History and Legacy of Louisiana's Free People of Color, ed. Sybil Kein (Baton Rouge: Louisiana State University Press, 2000), 179-195; Lester Sullivan, "Composers of Color of Nineteenth Century New Orleans: The History Behind the Music," Black Music Research Journal 8 (1988) : 11-41; Louis Haber, Black Pioneers of Science and Invention New York: Harcourt, 1970); Rodolphe Lucien Desdunes, Our People and Our History, trans. Sister Dorothea Olga McCants (Baton Rouge: Louisiana State University Press, 1973); and Charles Edward O'Neill, Victor Séjour, Parisian Playwright of French Louisiana (Lafayette, La.: Center for Louisiana Studies, University of Southwestern Louisiana, 1996).

${ }^{31}$ The free populations in the Caribbean seem to be better researched and several outstanding studies exist concerning the free populations in the Caribbean. See Dorris Lorraine Garraway, The Libertine Colony: Creolization in the French Caribbean (Durham: Duke University Press, 2005); 
Caribbean concubinage developed early between slave and master. In contract to the Anglo-Saxon American colonies, French authorities were more concerned about the moral, as opposed to the racial, consequences of concubinage. As a result, a few French priests in the French islands were willing to consecrate the unions between white men and black or mulatto women. Consequently, issues arose over the status of the resulting children. When told to develop a general slave code for French territories, Governor Charles de la Roche Courbon de Blénac and colonial Intendant Jean-Baptiste Patoulet clashed over the status of these offspring. ${ }^{32}$ De Blénac argued that the mulatto children born to slave mothers should be freed as they would more easily adapt to white culture and customs. He also encouraged the marriage between free mulatto women and French men as a mean to populating the territory. De Blénac pointed to the Spanish and Portuguese practice of such methods of population as successful precedent. ${ }^{33}$ The contest between de Blénac and Patoulet are visible in the original draft of the Code Noir of 1685 and also in the Code Noir drafted in New Orleans in 1724.

The Code Noir of 1724 explicitly prohibited sexual relations of any kind, whether marital or non-marital, between Africans - either free or enslaved — and

Meagan Vaughan, Creating the Creole Island: Slavery in Eighteenth-Century Mauritius (Durham: Duke University Press, 2005) ; Carl A. Brasseaux and Glenn R Conrad, eds., The Road To Louisiana: The Saint-Domingue Refugees, 1792-1809, (Lafayette: Center for Louisiana Studies, University of Southwestern Louisiana, 1992) ; Gwendolyn Midlo Hall, "St. Domingue," in Neither Slave Nor Free: The Freedmen of African Descent in the Slave Societies of the New World, eds., David W. Cohen and Jack P. Greene (Baltimore: Johns Hopkins University Press, 1972), 172-192.

\footnotetext{
${ }^{32}$ Aubert, “"The Blood of France," 12-14.

${ }^{33}$ Aubert, "The Blood of France," 14.
} 
Europeans. The colonists accepted this news, "with neither complaint nor praise but rather with silence." ${ }^{34}$ The silence was telling; many French considered love to be a private affair, not one to be proscribed by law or scripture. Sex, nonetheless, argues historian Jennifer Spear, ceased to be a private matter but became one of state whereby the French crown attempted to legislate carnal relations in order to "further their colonial goals and control colonial populations. ${ }^{, 35}$ Regardless of the official political line, one member of the clergy noted that "many inhabitants live almost publicly with colored concubines," and did not hesitate to take their children from such relationships to the local church to be baptized and "recorded in the registries as their natural children., 36

In the French Caribbean, one observer noticed that the sophistication, good business sense, and "the elusive Rousseauian trait of sensibilité" made free women of color more preferable to white men as partners. ${ }^{37}$ The attraction was not purely physical; many of these women commanded considerable fortunes of their own in either the form of land, slaves, or other holdings. These women were, according to Caribbean historian Doris Garraway, on average, more independent and financially stable than white women - a concept that will be discussed in Chapter Three.

\footnotetext{
${ }^{34}$ Jennifer Spear, "Colonial Intimacies: Legislating Sex in French Louisiana," The William and Mary Quarterly 60:1 (Jan. 2003) : 75.

${ }^{35}$ Spear, "Colonial Intimacies," 76.

${ }^{36}$ Laura Foner, "The Free People of Color in Louisiana and St. Domingue: A Comparative Portrait of Two Three-Caste Societies,” Journal of Social History 3 (Summer 1970): 411.

${ }^{37}$ Dorris Garraway, The Libertine Colony: Creolization in the Early French Caribbean (Durham: Duke University Press, 2005), 235.
} 
French cultural and legal attitudes, argues Louisiana historian Jerah Johnson, did not arrive directly from the motherland, but were filtered through the French colonies in Canada. The experiences of French colonial Louisiana can be viewed as a direct outgrowth of the French experience in Canada. In Canada, as in France, Colbert, the minister of finance, and King Louis XIV promoted assimilating Native Americans into French society. By turning Indians into Frenchmen, the French government could better control the native population. Furthermore, Richelieu, in his Etablissements de la Compagnie de Canada sous le titre de Nouvelle France circa April 29 and May 7, 1627, hoped that the natives would be "deemed and respected to be natural-born Frenchmen, and as such may come to dwell in France when it shall seem good to them.."38 Colbert idealistically hoped for "one [French] people and one blood. 39

Colbert proceeded to initiate a full-scale policy of intermarriage between French-Canadian settlers and local Indian women. He encouraged European women to marry Indian men, as well. Colbert even created a dowry fund for the sole benefit of women of one race who married men of the other. ${ }^{40}$ Assimilation is not a process that

${ }^{38}$ Cardinal Richelieu, Etablissements de la Compagnie de Canada sous le titre de Nouvelle France (April 29 and May 7, 1627); quoted in Jerah Johnson, "Colonial New Orleans: A Fragment of the Eighteenth-Century French Ethos," in Creole New Orleans: Race and Americanization eds. Arnold R. Hirsch and Joseph Logsdon (Baton Rouge: Louisiana State University Press, 1992), 21.

${ }^{39}$ Mack Eastman, Church and State in Early Canada (Edinburgh, 1915), quoted in Jerah Johnson, "Colonial New Orleans: A Fragment of the Eighteenth-Century French Ethos," in Creole New Orleans: Race and Americanization, Arnold R. Hirsch and Joseph Logsdon eds. (Baton Rouge:

Louisiana State University Press, 1992), 23.

${ }^{40}$ Jerah Johnson, “Colonial New Orleans," 23. 
happens immediately and despite admirable efforts, the French attempt in Canada started to decline but not before French Canadian courreurs $d u$ bois transplanted their colonial and frontier mentality and experiences to Louisiana. The parallels between Canada and Louisiana, Johnson says, are striking. Both colonies learned to thrive while frequently neglected by their mother country, suffered from a shortage of supplies and support, and lacked a sustainable population of Frenchmen and women. Lastly, and most-notably, European-Indian relations in both colonies directly contributed to the survival of both colonies. Policy such as this, wrote historian Gary Nash, led to "a far greater degree of interaction between the cultures in New France than in England's colonies." 41

As Louisiana increasingly became a drain on the French exchequer, King Louis XIV, no longer willing to bear the burden of Louisiana, gifted the colony to his cousin, the king of Spain. Spain officially took control of Louisiana upon the conclusion of the Seven Years' War in 1763. Spain would hold the territory for almost forty years, yet the people, culture, and language remained stubbornly French in nature. Even under American rule, the city of New Orleans retained its distinctive French sensibilities and loyalties. Inevitably, elements of both Spanish and American cultures infiltrated the city, yet most families continued to honor their Francophile ancestors and raised their children to speak French. Even the Spanish seat of colonial

\footnotetext{
${ }^{41}$ Gary B. Nash, Red, White and Black: The Peoples of Early America (Englewood Cliffs,
} 1974), 106. For more on the interaction between French Canadian males and Native American females, see Sylvia Van Kirk, Many Tender Ties: Women in Fur-Trade Society, 1670-1870 (Norman, OK: University of Oklahoma Press, 1980); Karen Anderson, Chain Her by One Foot: The Subjugation of Women in Seventeenth-Century New France (London: Routledge, 1999). 
government, the Cabildo, explained Louisiana historian Jerah Johnson, as a purely venal institution, became staffed by members of the rich French Creole families who could afford to purchase the offices, not Spanish officials. The Spanish language never superseded French, and was primarily used in legal documents and proceedings only. The Spanish military in Louisiana, ironically, was not entirely Spanish, or even principally Spanish; in fact, slightly less than half of the men were Spanish. ${ }^{42}$

By the time Spain gained control of Louisiana, a social system developed that accommodated a large degree of autonomy and room for a growing, increasingly prosperous free black community. Spain hoped to continue the relatively lenient legal system of slavery as it existed under the French. The Spanish system of slavery, in theory, encouraged patriarchy, Catholicism, and the supremacy of the white race. In practice, however, Spanish law provided for the rights of slave manumission, selfpurchase, the right to own property, and the right to judicial protection when warranted. Slavery, by nature, was cruel and harsh, but nevertheless many men and women found the means to survive and eventually leave slavery behind. Slavery, wrote Virginia Meacham Gould, was a constant process of negotiation between slave and master, a daily struggle between individual and master, regardless of which cultural paradigm prevailed. ${ }^{43}$

\footnotetext{
${ }^{42}$ Jerah Johnson, "Colonial New Orleans," 47.

${ }^{43}$ Meacham Gould, "In Full Enjoyment of Their Liberty," 79.
} 
Interaction among slaves and whites in New Orleans could be startling and baffling for visitors, particularly those from the North United States. Many travelers commented on the commingling of cultures and people in the streets of New Orleans. "On arriving at New Orleans," wrote architect Benjamin Henry Latrobe, "a sound more strange than any that is heard anywhere else in the world astonishes a strange. It is a most incessant, loud, rapid, and various gabble of tongues of all tones that were ever heard at Babel. It is more to be compared with the sounds that issue from an extensive marsh, the residence of a million or two frogs . . than to anything else." ${ }^{44}$ The strange and curious sound Latrobe wrote of turned out to be the voice of the various peoples of the market along the banks of the Mississippi and the levee. The appearance of the people in question further astonished Latrobe: "White men and women, and of all hues of brown, and of all classes of faces, from round Yankees to grizzly and lean Spaniards, black negroes and negresses, filthy Indians half naked, mulattoes curly and straight-haired, Quadroons of all shades, long haired and frizzled, women dressed in the most flaring yellow and scarlet gowns ..."

In one quick observance Latrobe (possibly unconsciously) touched upon the curious nature of the racial, sexual, social, and ethnic complexities of the city. Living, breathing, proof of New Orleans' frontier nature and the prevalence of miscegenation greeted Latrobe immediately upon his arrival. The "mulattoes curly and straighthaired," and the "Quadroon of all shades," announced the free community of color and

${ }^{44}$ Benjamin Henry Latrobe, The Journal of Latrobe: Being the Notes and Sketches of an Architect, Naturalist, and Traveler in the United States from 1796-1820 (New York: D. Appleton and Company, 2005), 160-161. 
its highly visible presence in New Orleans. A visitor could not behold such individuals without understanding the deeper meaning for local morality and social customs regarding the dynamics between whites and blacks. Such behavior and intermingling of whites and slaves would certainly be unheard of in the Northern states.

Further influencing the frequency of interaction, residential housing in New Orleans was not racially segregated as in many other cities. Whites and free Creoles lived in the same neighborhoods, shared churches and the marketplace. ${ }^{45}$ Upper-class whites, observed hairdresser Eliza Potter, had no fear of public disapproval and "no need for artificial props for their egos," resulting in frequent violation of social taboos. ${ }^{46}$ This means that they regularly hired free blacks to teach their children, entertained them for dinner, or attended the same social functions. On occasion, the more brazen, wealthy white men went so far as to register their natural mulatto children in public schools. ${ }^{47}$

In urban centers, New Orleans in particular, slaves enjoyed a much more social life than those residing on the plantations. The majority of an urban slave's day could be relatively free of white supervision, or at least away from his master's watchful

\footnotetext{
${ }^{45}$ Interestingly enough, while neighborhoods did not segregate strictly along racial lines, they did segregate along cultural lines with the local French Creoles living predominately in the original quarter of the city along the Mississippi known as the Vieux Carré and the Americans, upon their arrival, creating neighborhoods upriver in the Faubourg St. Marigny. Even the architecture of the houses and buildings in each faubourg differed according to the predominant cultural influence.

${ }^{46}$ John Blassingame, Black New Orleans, 1860-1880 (Chicago: University of Chicago Press,
} 1973), 9.

\footnotetext{
${ }^{47}$ Blassingame, Black New Orleans, 10.
} 
eye. Many dressed lavishly and took pleasure in rich foods, candies, wines, liquors, and dancing. Sunday, legally their day off as prescribed by the Code Noir, frequently involved gambling, drinking, socializing in restaurants and barbershops, or dancing in Congo Square. ${ }^{48}$ As most urban slaves served as domestics or household slaves, many adopted or mimicked the cultural attitudes and habits of their white masters, including, according to prominent historian of black New Orleans John Blassingame, white attitudes towards marriage. As a result, many urban slaves were married in churches and developed a much more sophisticated culture than that of plantation slaves. ${ }^{49}$

The line between free and enslaved frequently blurred and could be difficult to enforce, illustrating how closely the two ethnic groups were aligned in antebellum New Orleans and certainly how complex race relations had become. The prevailing attitude toward blacks and mulattos appears to be nowhere near as clearly defined as that in the North. Noted historian of Louisiana, Gwendolyn Midlo Hall argues that there is no evidence to suggest that the racial exclusivity and contempt of white for black exhibited in recent times existed in antebellum New Orleans. The color line proved more permeable and fluid that would be expected. ${ }^{50}$

\footnotetext{
${ }^{48}$ Blassingame, Black New Orleans, 1-2.

${ }^{49}$ Blassingame, Black New Orleans, 4-5.

${ }^{50}$ Passing in colonial and antebellum New Orleans proved difficult due to the relatively small size of the population where the lineage of even the lightest families of color was public knowledge. It was possible, however, for those of the lightest shades to leave Louisiana and pass into white society in the North or in Europe. After the Civil War those who could not easily pass as white became black by default. Emancipation effectively eliminated the tenuous designation as gens de couleur libres forcing these men and women into either the black or white community.
} 
Regardless of their legal status as enslaved, many slaves found a way to change their situation and station. Under French occupation manumission was acceptable, but not encouraged. Under Spanish occupation, manumission increased at a rapid pace. The Spanish census taken in 1778, recorded 601 free persons of color, 248 of which were considered mulattoes, or born free living in New Orleans.

Comparatively, in other Spanish North American holdings, by 1788 Mobile claimed 88 free persons of color and from 784 to 1820 , Pensacola witnessed the growth of their free population from 27 to $252 .^{51}$ Spanish practice allowed a master to free a slave simply by filing an escribano, or an act recorded by a notary. As a result, slave manumission increased, adding to the free population. Slaves could also purchase themselves under the system of coartacion, or self-purchase. The Spanish codicil, Las Siete Partidas admonished all citizens to encourage manumission as "all judges should aid liberty, for the reason that it is a friend of nature, because not only men, but all animals love it." ${ }^{52}$

The sale of light-skinned female slaves, frequently referred to as "fancy maids," proved to be a profitable business for nineteenth-century slave traders. In 1834, the slave trader Isaac Franklin wrote to Rica Ballard, his partner, about the acquisition of a "fancy" girl that Ballard had retained. Franklin insinuated that Ballard kept the young woman for his own sexual gratification and that in such an event,

${ }^{51}$ Meacham Gould, "In Full Enjoyment of Their Liberty," 82.

${ }^{52}$ The Laws of Las Siete Partidas, Which are Still in Force in the State of Louisiana, trans. L. Moreau Lislet and Henry Carleton, vol. 1 (New Orleans: James M'Karaher, 1820). 
Ballard needed to pay Franklin the $\$ 1,100.00$ she was worth on the open slave market. ${ }^{53}$ This exchange illustrates the demand for and lucrative nature of trading light-skinned mulatto women. Southern historian Edward Baptist suggests that the correspondence demonstrates that Franklin and his colleagues wanted mulatto women not only as bodies to sell, but also as bodies to sexually exploit for their own desires. This further suggests a deeper meaning for historians of Southern and slave historyone that challenges the foundation of the white/black dichotomy and sexuality. The desire of white men for light-skinned women hints at a deeply rooted, highly sexualized fetishism that fueled the Southern slave trade and influenced the development of Southern culture, as evidenced by the rapid growth of the mulatto population. The traders, one could argue, can be held responsible for encouraging the growth of this third cross-section of the population. ${ }^{54}$

In sexual relationships between slave and slave owner, consent largely proved to be a virtual non-issue yet there is evidence that demonstrates the relatively common practice of a slave owner demonstrating long-term commitment to a particular slave woman. Because of the master/slave dynamic it is difficult to categorize such a relationship and would not be prudent to assume the relationship was entirely onesided and predatory. Research shows that female slaves employed a variety of methods to resist unwanted advances from white men and courted their favor in

${ }^{53}$ Isaac Franklin to R.C. Ballard, January 11, 1834, folder 13 Series 1.1, Rice Ballard Papers, Southern Historical Collection, University of North Carolina, Chapel Hill, North Carolina, quoted in "'Cuffy,' 'Fancy Maids,' and 'One-Eyed Men': Rape, Commodification, and the Domestic Slave Trade in the United States,' Edward E. Baptist, The American Historical Review 106:5 (Dec. 2001), 1619.

${ }^{54}$ Baptist, “'Cuffy,' 'Fancy Maids,' and 'One-Eyed Men,' 1619-1620. 
others. In some of these cases the white slave owner recognized the offspring as his own, in either wills or by outright acknowledgement, a practice that will be further addressed in a subsequent chapter.

Whether the relationships between European men and women of color were consensual or forced, it appears, according to Gould's research, that approximately 42 percent of the emancipated adult slave women in New Orleans received their freedom from their lovers. ${ }^{55}$ In New Orleans, as in other Spanish port cities such as Pensacola and Mobile, to liberate one's slave concubine was a perfectly acceptable practice. Records officially listed many such manumissions as a result of "well and faithful" service.

The words "Well and faithful service" appear in the manumission records frequently, but it must be understood that the term most often served as a substitute for the actual reasons for manumission of many female slaves — chief among them being a sexual relationship of some sort between master and slave, particularly when the relationship resulted in children or lasted for a lengthy duration. This is not to say that all slaves liberated for "well and faithful service" did not earn their freedom from actual faithful service and loyalty; however, the emancipation of children and women far surpassed that of men, leading to the conclusion that many emancipations resulted directly from master/slave sexual relationships. Gould explained that several factors increased the chances of female emancipation, but one avenue particularly increased a woman's chance at freedom: a connubial relationship with her master. Historically

\footnotetext{
${ }^{55}$ Meacham Gould, "In Full Enjoyment of Their Liberty," 90.
} 
speaking, black women are typically portrayed as victims of white lust, thus stripping them of any agency. Many historians who examine the prevalence of interracial relationships in colonial Louisiana fail to leave room for female agency. Furthermore, historian Jennifer Spears points out that by depicting European men as "overcoming" their racial prejudices to copulate with black women, historians assume that all European men were predisposed toward European women. But as evidenced by the research of Gwendolyn Midlo Hall, European men continued to show a preference for relationships with Wolof and other African women, even with a broad selection of white women available. ${ }^{56}$

Another motivating factor for the emancipation of slave mistresses may be the disruption caused by the mistress's presence in the master's household. Representative Tanner of Rapides Parish asked, "Do you wish to retain a negress with whom he has lived in concubinage under the roof or in the neighborhood of the legitimate white wife? ... the woman and her bastard brood should be sent away. Her presence can only engender quarrels and turn the domestic hearth into moral hell. ${ }^{57}$ Representative Tanner clearly did not have the well being of the black mistress in mind; however, such an attitude did facilitate the liberation of many women and children, fueling the growth of the free population of color. Numbering 858 between 1771-1791, and increasing to 1,335 by 1797 , the population of free people of color continued to grow.

${ }^{56}$ Spear, "Colonial Intimacies: Legislating Sex in French Louisiana," 78.

${ }^{57}$ Official Reports of the House of Representatives of the State of Louisiana (1854), 14-16, quoted in Gould, "In Full Enjoyment of Their Liberty," 98. 
The free population of people of color (meaning not liberated blacks) composed 34 percent of New Orleans' total population. ${ }^{58}$ The city claimed a population of 2,312 in 1806 , and 13,076 in $1840 .^{59}$

Immigration from other French colonies further bolstered the free population, especially that from the sugar colonies of the Caribbean. Between the years of 1791 and 1804, refugees from Saint Domingue flooded into the colony. A last wave arrived in 1809 , bringing with it a total of 3,102 free persons of color. ${ }^{60}$ The Louisiana Creole language particularly appealed to the refugees, as it closely resembled the Haitian Creole of the islands. Furthermore, the elite of both communities spoke French. Louisiana's climate and plantation-based economy also closely paralleled that of Haiti. ${ }^{61}$ Many of these Francophile immigrants arrived with fortunes and slaves of their own (most of which were female), adding to the overall prestige and wealth of the class as a whole. Educated and skilled, the immigrants intermarried with the local population and by the 1830 s foreign-born free people of color represented fifteen percent of all non-white Catholic spouses in New Orleans. ${ }^{62}$

\footnotetext{
${ }^{58}$ Meacham Gould, "In Full Enjoyment of Their Liberty," 93.

${ }^{59}$ Meacham Gould, "In Full Enjoyment of Their Liberty," 95.

${ }^{60}$ Paul F. Lachance, "The Foreign French," in Creole New Orleans: Race and Americanization
} eds. Arnold R. Hirsch and Joseph Logsdon (Baton Rouge: Louisiana State University Press, 1992), 105.

${ }^{61}$ Gwendolyn Midlo Hall, "The Franco-African Peoples of Haiti and Louisiana," Southern Quarterly 44:3 (Spring 2007), 13.

${ }^{62}$ Lachance, "The Foreign French," 116. 
New Orleans offered a safe haven to the free people of color fleeing Saint Domingue and Cuba. Their presence further solidified the third class, creating a caste system that, Alice Dunbar-Nelson argues, was almost as strong as that in India. ${ }^{63}$ Within this system free people of color continued to amass wealth and educate their children. Those who could afford it sent their children to France to become educated in a French manner; others attended the schools developed by and for the benefit of free people of color. As the community of color grew in wealth, education, and influence, young, affluent European men began pursuing amorous relationships with women of this community. Competition for the most beautiful, graceful, and accomplished of these women grew fierce. Hairdresser Eliza Potter remembered one young man who became fatally besotted with a young Quadroon. Upon learning that she took another man as her placer, the youth went home and committed suicide. These occurrences, wrote Potter, were all too frequent and she could "neither find paper nor time to tell you half of such things as came under [her] notice." ${ }^{64}$

The men who took mistresses of color did not lose face or prestige in the eyes of respectable, white society. To many outside observers the prevalence and openness with which many plaçage relationships were conducted might suggest that the taking of a light-skinned Quadroon mistress was almost a rite of passage for wealthy Creole young men. White women reacted to this practice in a variety of ways. Some simply

${ }^{63}$ Alice Dunbar-Nelson, "People of Color in Louisiana: Part II," The Journal of Negro History 2:1 (Jan. 1917), 61 . 161.

${ }^{64}$ Eliza Potter, A Hair-Dresser's Experience in High Life (Cincinnati: For the author, 1859), 
closed their eyes and turned away from the reality of their husbands', sons', and grandsons' activities. Others made their spouse's lives uncomfortable and as miserable as possible. White women could legally have a free Creole woman of color whipped in public for even minor infractions. More than one white wife attempted to deliver such retribution on her husband's Quadroon mistress. But this tactic could just as easily backfire, with the enraged husband, indignant at the treatment of his mistress, lashing out at his wife. Many men fought duels defending their mistresses, making it clear they would not abide any mistreatment of these women.

Even visitors to the city, who may otherwise have disapproved of plaçage and open interracial unions could not but help admire the intelligence and grace of the more elite free population. Charles Lyell, an astute visitor to Louisiana, noted, in 1849 , that "if colored men had fair play, and were carefully educated, they might soon be safely entrusted (sic) with equality of civil and political rights. Whatever may be their present inferiority as a race, some of them have already shown superior abilities to a great many of the dominant whites. ${ }^{.65} \mathrm{He}$ was further impressed with the intellect of the mulatto offspring of the white and free Creole population, finding them a brilliant amalgamation. This "historical intimacy," wrote Blassingame, led most white Louisianans to have "far less abhorrence for blacks than did their brothers in the North and far less than their rhetoric often implied." ${ }^{66}$ The education, wealth, and refinement

${ }^{65}$ Sir Charles Lyell, A Second Visit to the United States of North America, vol I. (New York: Harper Brothers, 1849), 105.

${ }^{66}$ Blassingame, Black New Orleans, 11. 
of the upper class free Creoles of color further facilitated convivial relationships between their community and the white community while creating distance between themselves and the less-educated black population. The greater the distance, socially and financially, between the free community and the enslaved or recently freed blacks, the more secure the gens de couleur libres felt.

Wealth and education served as another marker distinguishing the free Creoles of color from the free blacks. The free population of African descent in the French colony of Saint-Domingue wielded a fair amount of social and economic clout, more so than their contemporaries in Louisiana. In the wealthy Caribbean sugar colony, this population controlled one-third of all cultivated land and owned numerous slaves, prior to the French Revolution. ${ }^{67}$ Unlike Louisiana during the same time frame, SaintDomingue was rapidly becoming a dynamic colony, one with hospitals, theaters, and local newspapers. Unlike Louisiana, the elite population of Saint-Domingue enjoyed relative freedom from a strong, centralized government fostering a "thirst for autonomy." ${ }^{68}$ In addition, the free population in Saint-Domingue felt free to protest despotic economic or social sanctions, and viewed politics as a viable, preferable solution for social discontent. The Creoles of Saint-Domingue continuously pushed for

${ }^{67}$ Nathalie Dessens, From Saint-Domingue to New Orleans: Migration and Influences, (Gainesville: University Press of Florida, 2007), 9.

${ }^{68}$ Dessens, From Saint-Domingue to New Orleans, 10. With the commencement of the Haitian Revolution in August 1791, the free population of Saint-Domingue, both white and free people of color, united to work against the rebelling slaves. By late September, according to Dessens, the insurgents had slaughtered 1,000 people and burned 161 sugar plantations and 1,200 coffee plantations, reportedly causing approximately 600 million Livres worth of damage. See Dessens, 12-13. 
autonomy and official recognition as a group, particularly in light of the French Revolution. In 1791, however, a new revolution was brewing in Saint-Domingue, one where no solidarity existed between people of African descent. When it became apparent that the slaves of Haiti would not be subdued, thousands of refugees fled the colony, many bound for North America, with New Orleans as a favorite port of call. ${ }^{69}$

The wealth of the gens de couleur libre grew under many occupations. The Soulie brothers, Albin and Bernard, founded an estate worth at least $\$ 500,000$, as capitalists, merchants, and brokers. According to historian Juliet E.K. Walker, at least nine free men of color held property or business capital estimated between $\$ 150,000$ and $\$ 250,000$. Seven claimed a fortune estimated at $\$ 100,000$. Among these wealthy free Creoles were cotton planters, capitalists, a merchant, and at least two master tailors. $^{70}$

Many members of the white community resented the success of the gens de couleur libres, yet even in the face of such bitter resentment they flourished and their own community grew. "They [Creoles of color] did not assume," wrote Louisiana historian Charles Gayarré, "that fawning posture of debasement attributed to them by

${ }^{69}$ Dessens, From Saint-Domingue to New Orleans, 21-45. For more on the Saint-Domingue immigrants see Carl Brasseaux, ed. A Refuge for All Ages: Immigration in Louisiana History, vol. 10 of the Louisiana Purchase Bicentennial Series in Louisiana History (Lafayette: University of Southwestern Louisiana Press, 1996); Carl Brasseaux and Glenn R. Conrad, eds. The Road to Louisiana: The SaintDomingue Refugees, 1792-1809 (Lafayette: Center for Louisiana Studies, University of Southwestern Louisiana, 1992); Thomas Fiehrer, "Saint-Domingue/Haiti: Louisiana's Caribbean Connection," Louisiana History 30:3 (Fall, 1989), 419-437.

${ }^{70}$ Juliet E.K. Walker, "Racism, Slavery, and Free Enterprise: Black Entrepreneurship in the United States before the Civil War," The Business History Review 60:30 (Autumn, 1986), 352. 
writers of novels and dramas, nor did their faces wear an expression of Byronic despair." ${ }^{71}$ Instead they, "walked erect, they smiled, and even laughed; they looked fat, sleek, and contented ....72 According to Gayarré, even if the community experienced discontent or resentment, they did not let such feelings get in the way of their success and accumulation of wealth. They continued to exercise their full liberties under the law and shape their lives according to real and de facto regulations.

The finest example of the intelligence, industriousness, and business acumen of the free community is William Alexander Leidesdorff. Leidesdorff, who died at age thirty-eight, amassed a fortune of $\$ 1.5$ million dollars. Born in the Dutch West Indies to a Dutch father and mulatto mother, Leidesdorff became America's first black millionaire. ${ }^{73}$ Leidesdorff certainly profited from his connection to the Anglo world, and he was not the only one to do so. Much of the initial wealth and capital of the gens de couleur libres came from white fathers or benefactors. James Forten, born free, apprenticed himself to a white sail maker and ultimately became one of the wealthiest men in his trade. Andrew Durnford found his mentor in John McDonough, a white planter, and became a successful planter in his own right. Durnford was the son of a placée and a white father who maintained a friendship with McDonough who in turn,

\footnotetext{
${ }^{71}$ Charles Gayarré, "Historical Sketch-The Quadroons of Louisiana," English Version, Special Collections, Hill Memorial Library, Louisiana State University, Baton Rouge.

${ }^{72}$ Gayarré, "Historical Sketch," 5.

${ }^{73}$ Walker, "Racism, Slavery, and Free Enterprise," 355. As an interesting note, Leidesdorff frequently passed as white and after the Civil War he became the city treasurer for San Francisco.
} 
assisted Durnford in his business ventures. ${ }^{74}$ It was such close business alliances as these that so closely intertwined the free community of color and white to such a unique degree and enabled the growth of many free Creole institutions and organizations. The desire, observed Charles Gayarré, "of distinction and of rising to superior social association . . is implanted by nature in the human heart." 75

Despite the existence of such close relationships, many in white society did not welcome people of color, no matter what their economic level of success; consequently, these Creoles created their own institutions and organizations. Founded in 1840, the Ecole Des Orphelins Indigents became the first school ever opened to free children of color in the United States. Created from funds left by a free woman of color and further financed by two additional, separate benefactors of color, the school educated many children, both orphaned and not. ${ }^{76}$ The Ecole offered an education that rivaled, if not surpassed, that of the white schools.

Another institution of paramount importance to the free community of color was the Sisters of the Holy Family, and by further extension, the Catholic Church. The Catholic Church held a special position within the community of gens de couleur libres. Many travelers commented on the nature of Catholicism and worship in New Orleans, astonished at how the whites and blacks prayed together at the St. Louis

\footnotetext{
${ }^{74}$ Walker, "Racism, Slavery, and Free Enterprise," 363.

${ }^{75}$ Gayarré, "Historical Sketch," 9.

${ }^{76}$ Dunbar-Nelson, "People of Color in Louisiana: Part II," 65.
} 
Cathedral. Every Sunday the pews of the cathedral filled with whites and mulattoes, all coexisting in peace for the sake of the Sabbath.

Historians argue over the actual influence of the Saint-Domingue refugees, but it is undeniable that the great influx of free Creoles of color impacted Louisiana. The refugees reinforced the strength and mentality of the free Louisiana population. The population of Louisiana was small and according to Dessens, impressionable and ripe for cultivation. ${ }^{77}$ The comparatively sophisticated and urbane Creoles of color from Saint-Domingue brought their industry, activism, and motivation to Louisiana, leading to the development of more sophisticated institutions, charities, culture, skills, and ultimately communal identity.

The arrival of the Saint-Domingue refugees served to essentially double the population of free people of color in Louisiana, inciting fear and apprehension in the white populace. Legally speaking, any free male of color over the age of fifteen was not allowed to enter Louisiana. However, like many other laws in Louisiana, theory and practice diverged and all the refugees were accepted into, and taken care of, by the local gens de couleur libres. The social structure in Louisiana was, wrote Dessen, "sufficiently close to what the refugees had left behind to give them a sense of familiarity but presented enough differences to offer them space for insertion and influence." 78 The white Creole community warmly welcomed the white refugees, viewing their arrival as a fortuitous means by which to bolster their community against

\footnotetext{
${ }^{77}$ Dessens, From Saint-Domingue to New Orleans, 38-39.

${ }^{78}$ Dessens, From Saint-Domingue to New Orleans, 45.
} 
the ever-increasing population of Anglo-Saxon-Americans. The new American stewards of Louisiana had hoped to rapidly Americanize Louisiana, but met with hearty resistance from both Creole communities who tenaciously clung to their French roots. The French ethos proved so deeply entrenched in New Orleans that to this day tension exists between the oldest wealthy Creole families and "new" American interlopers.

The inclusion of the Saint-Domingue émigrés cannot be called seamless, but it was, nevertheless, fairly smooth, due in large part to the fact that the refugees consisted of three similar groups to those that already existed in Louisiana: enslaved, white, and free people of mixed Afro-Caribbean-French ancestry. Not long after their entrance into the Louisiana community, the newcomers insinuated themselves into the local economy. The island émigrés exhibited a much stronger influence in Louisiana than in other cities, points out Nathalie Dessens, given the nature of Louisiana's economic structure and because the local population closely resembled their own. Such qualities, contends Dessens, led to "a success story," for the refugee community. ${ }^{79}$

The arrival of such great numbers of Francophiles wrought not only social and economic changes, but also cultural transitions as well, alternately introducing new practices as well as reinforcing preexisting ones. Much to the chagrin of the Americans, the refugees were considered to be responsible for reinforcing, and in

${ }^{79}$ Dessens, From Saint-Domingue to New Orleans, 69.Dessen compares and contrasts the impact of the Santo-Domingue refugees in various seaports of the American Atlantic in Nathalie Dessens, From Saint-Domingue to New Orleans, 67-68. 
some cases, introducing "European culture, with all its pleasures and vices to the erstwhile provincial town." ${ }^{80}$ Among these "vices" was the practice of plaçage. While not new to Louisiana, plaçage had flourished to a much larger degree in SaintDomingue where the exotic women were knows as "Les Sirènes." The difference between the Louisiana practitioners and those from the islands, explained Nathalie Dessens, is that the Saint-Domingan transplants practiced plaçage much more openly, visibly, and with less hypocrisy. ${ }^{81}$ Some white refugees even brought their Quadroon consorts and children with them.

Dance proved to be another tradition reinforced by the Haitian refugees, one that went hand in hand with, but did not necessarily precede, plaçage. In SaintDomingue, as in the white community, dances provided a place for young men and women to meet and develop a courtship. They offered entertainment and a reputable place for interaction. In New Orleans, however, specific balls offered different, yet similar opportunities, by which wealthy white men could meet the more elite free women of color.

The influx of Saint-Domingan refugees bolstered the free community and helped to shore up its bourgeoning identity. Many aspects of the community mimicked those of the white community, yet the elite men and women of the mixed Creole community created a unique position for themselves and their children. By practicing

\footnotetext{
${ }^{80}$ Winson C. Babb, "French Refugees from Saint Domingue to the Southern United Sates, 1791-1810," (Ph.D diss, University of Virginia, 1954), quoted in Dessens, From Saint-Domingue to New Orleans, 104.

${ }^{81}$ Dessens, From Saint-Domingue to New Orleans, 104.
} 
plaçage and patronizing the balls, the Haitian immigrants, both white and black, contributed to the growth of the elite free population, increasing the education of and cash flow into the community. In what seems to be a natural progression, the free community embraced its unique position within Louisiana society and continued to capitalize on whatever benefits could be derived from close association with the white community.

From the earliest days of the colony, white men and women of color, whether Indian or African, mingled, frequently resulting in children. Far from their motherland and the overriding grip of royal and religious authority, the men and women of colonial Louisiana unwittingly set about creating a third caste of people, resulting from interracial unions of varying commitment, and endurance. Many members of this community remained poor and impoverished; yet several went on to create an elite, educated, talented subgroup. This portion of the community accumulated wealth and material goods largely due to their connections with wealthy white fathers, uncles, and lovers, most of which were the result of plaçage relationships. Regardless of where the initial wealth came from, the community capitalized on access to education and resources to better themselves and ultimate create a solid, prosperous community and proud identity, firmly set above that of their enslaved counterparts, and only slightly below that of the whites. By the early nineteenth-century the vibrant community was such that it astounded visitors and rarely failed to elicit alternately admiration, shock, curiosity, and revulsion. 


\section{Chapter Two \\ Sui Generis: Myth and Reality of the Fabled Quadroon Balls}

\section{The Quadroon Ballroom}

Where "fore the war, in days of glory old, When wealth and fashion set the paces high, When morals and strange customs held their code, The quadroon girl made white men dance and sigh.

The half-white woman was a creature strange,

A petted, fawning thing, of love and sin.

Her beauty was a dream surpassing rare, Whose charms their masters oft' in fight did win. And proud, these girls were petted darlings fair, Whose sight the grand dames did then hate and fear;

For in their ballroom vast were reveals held, Which brought the blush of shame and bitter tear.

There Folly led the dance in madness wild, When rivals, "neath the oaks would often meet,

In duel there, to place their lives at stake,

Because they found a quadroon girl so sweet. There flash'd the quadroon's eyes so soft and bright,

As on she flew, voluptuous in the dance; There breathed her land'rous beauty, wondrous, warm,

With sighs and words, the white man to entrance.

But now, where sin and folly once did reign,

A holy silence rests on cloister wall;

And noble colored Sisters life their race,

The quadroon girls, who long in sin did fall.

The orphan and the poor of that sad race

Find shelter there with God and holy rest;

The ignorant are taught and led from harm, Where Christ shall lead them to his kingdom blest.

$$
\text { Rixford J. Lincoln }{ }^{82}
$$

${ }^{82}$ Rixford J. Lincoln, "The Quadroon Ballroom," in Historical New Orleans: In Verse (New Orleans: s.n. 1911), 10. 
"The life of a Creole Quadroon was romantic and appalling and, in some ways, peculiarly pleasant."

Eleanor Early

Writing in 1834, architect John H.B. Latrobe described a quadroon ball that he attended with a friend. Instantly struck by "its beauty and brilliancy," he wrote, "The beauty of the ball room far exceeds anything of the sort that we have at the North which I have seen." The walls were richly gilded and ornamented in the regal colors of blue and gold, with five impressive gas light chandeliers hanging from the ceiling setting the large room ablaze. A live orchestra of colored musicians played from an elevated gallery in the antechamber. ${ }^{83}$ To a visitor, such as Latrobe, the display was dazzling and quite possibly startling, in all its glory. On the other hand, to a local, no less would be expected of such a soiree.

Modern-day New Orleans natives still take great pride in their long, illustrious tradition of music and dance. Every year crowds by the thousands converge on the city to enjoy its flashy presentation of Carnival; the city's elite costume themselves in the rich traditions of years past, dancing and reveling in plush, elaborate ballrooms festooned in green, purple, and gold while drinking the finest wines. Thousands more flood the city for Jazzfest, inducing some of the most well known names in jazz and the blues to participate. Jazz funerals remain a popular sendoff and every Sunday a

\footnotetext{
${ }^{83}$ John H.B. Latrobe, Southern Travels, Samuel Wilson, Jr. ed. (New Orleans: The Historic New Orleans Collection, 1896), 77-78.
} 
second line parade can be found. Dancing, wrote historian Henry A. Kmen, was an "extremely serious matter," in New Orleans. ${ }^{84}$ In the city's earlier years, before the implementation of sidewalks, women willingly hiked up their skirts and tromped through the muddy streets of New Orleans, followed by their slaves and attendants, bound for a dance or ball. After a quick stop for a footbath and a change of clothing, they danced the night away until it was once again time to tromp home. ${ }^{85}$ Dancing was, as Kmen asserted, serious business.

When one discusses dance in New Orleans, the fabled quadroon balls are almost always mentioned. Historically speaking, the quadroon balls received a large amount of attention, although most of the literature serves to simultaneously romanticize and vilify them. The majority of detailed descriptions left to historians come from out-of-town, or in some instances, out-of-country visitors, who found the quadroon balls a must-see attraction. The balls, spoken of in hushed voices by the locals, rarely failed to peak the curiosity of visitors who flocked to the dancehalls to witness the unique New Orleans' parade of race, gender, community, and romance. The spectacle of white men dancing the night away with women of color proved too interesting to pass up for even the most conservative of visitors. The record, therefore, is littered with descriptions that are alternately embroidered with innate biases and

${ }^{84}$ Henry Kmen, Music In New Orleans The Formative Years 1791-1841 (Baton Rouge: Louisiana State University Press, 1966), 4.

${ }^{85}$ Kmen, Music in New Orleans, 5. 
awe. In order to separate myth from reality it is necessary to first examine the historical and cultural context of dance in New Orleans.

The quadroon balls, much like the population of Creoles of color, grew out of the blending of New Orleans's frontier, melting pot culture, in a city cloaked in a seductive veil of mystery and an aura of sensuality and southern charm. The documented life of the balls, while not left by actual participants, is discernable: civil petitions, permits, newspaper accounts, and travel narratives bear testimony to their existence. Beyond these sources, memoirs and travel narratives occasionally mention the balls but the inherent prejudices of such accounts require careful use whether recorded by locals or visitors. Louisiana historian Donald Everett acknowledges that most of the observers focused exclusively on the salacious aspect of the balls, the mingling of whites and people of color, the dress and dance movements of the women. Such lascivious details offered no explanation as to how the population came to be so wealthy and refined. They did not dig deeper into the social implications of such dances yet they are often the only available and plentiful sources. ${ }^{86}$

For a relatively small, isolated outpost of the French and later Spanish, empires, entertainment in New Orleans needed to be easy to devise and simple to implement. Being relatively inexpensive, easy to coordinate, and reminiscent of the

${ }^{86}$ Donald Everett, "Free Persons of Color in Colonial Louisiana," Louisiana History 7 (1966), 35. The journals and observances of outsiders provide some of the richest material pertaining to the quadroon balls and even the women themselves. The women themselves did not leave written records or explanations for their activities, therefore I do rely upon these sources but have attempted to divine fact from prejudiced judgments. 
motherland, dances became a popular past time among many frontier societies. ${ }^{87} \mathrm{In}$ addition, dances did not require a high degree of conversation; Frenchmen, Spaniards, Indians, and Africans coexisted in the young colony, complicating communication among the population. Louisiana Governor Claiborne believed that not even one of fifty people spoke English. ${ }^{88}$ After the American occupation three main languages coexisted - French, Spanish, and English. Men and women remained faithful to whichever culture they most-closely associated with, adhering to its cultural, social, and linguistic traditions. Quadrilles, cotillions, and waltzes did not require verbal communication, therefore dancing effectively bridged the communication gap drawing together the disparate communities. Because the Latin-Catholic powers controlled New Orleans for its first century of existence, suggests Kmen, its people "escaped any notions that dancing was sinful. ${ }^{, 89}$ White, Anglo-Saxon Protestants from the North had difficulty accepting the fact that "Sunday was an especially popular day for dancing." 90

The high-spirited people of New Orleans threw balls for every thinkable occasion: Christmas, birthdays, elections, weddings, the Battle of New Orleans, George Washington and Andrew Jackson's birthdays, or visits by dignitaries. Subscription balls, masked balls, benefit balls, children's balls, and dances for any

\footnotetext{
${ }^{87}$ Kmen, Music in New Orleans, 10.

${ }^{88}$ Kmen, Music in New Orleans, 10.

${ }^{89}$ Kmen, Music in New Orleans, 10.

${ }^{90}$ Kmen, Music in New Orleans, 11.
} 
other various occasion never failed to be well-attended, festive affairs. ${ }^{91}$ For a territory so young, Kmen marvels, it required a certain amount of ingenious resourcefulness to find so many events worthy of celebration. By 1805 , dancers could choose between French, Spanish, or English atmospheres either within the city itself or as far away as Bayou St. John and across Lake Pontchartrain. If one wanted, they might board the steamer Mazeppa and sail into the Gulf of Mexico to Bay St. Louis and dance for two days before returning to the city on Monday morning. ${ }^{92}$

By no means did the white community hold a monopoly on dancing; free blacks had long been involved in New Orleans's dance scene. The most famous site of black dancers, Congo Square, provided a central location for gathering and dancing. ${ }^{93}$ Unlike the brutal, restrictive rural system of plantation slavery, urban bondage allowed for a greater deal of unsupervised movement and activity; therefore, it was not uncommon for slaves of lighter color to pass as free long enough to attend a ball or

${ }^{91}$ Dancing was such a serious affair in colonial Louisiana that children's balls were held regularly. The children's dances often proceeded the Grand Ball for adults, in the same ballroom. See the New Orleans L'Abeille, January 1, 1828. One witness wrote that the children "leap and caper with so much more pleasure, because their amusement is their only end." No mention is made as to what ends the adults worked toward but this may be construed as a cryptic reference to the quadroon balls and illicit love affairs; William Jeronimus, trans. C.J. Jeronimus, ed. Travels by His Highness Duke Bernhard of Saxe-Weimar-Eisenach Through North America in the Years of 1825 and 1826 (University Press of America, Inc.: New York, 2001), 63.

${ }^{92}$ Kmen, Music in New Orleans, 7-9.

${ }^{93}$ Congo Square originated not as a place of slave dancing, but as a marketplace during the early years of French colonial rule. It eventually became best-known as a location where slaves would gather on their free day to dance, play their handcrafted instruments such as the congaa and drums. Since the slaves of Louisiana came from various locations along the African coast and interior, the dances, instruments, and music blended several traditions and elements to create a truly unique and fascinating product. In the early years, voodoo rituals could also be witnessed at Congo Square. For more on Congo Square see Jerah Johnson, Congo Square in New Orleans (New Orleans: Louisiana Landmarks Society, 1995). 
enjoy a few drinks at one of the many taverns. Slaves residing within the city limits generally wore finer clothing, often handed down from their masters, further facilitating their charade as free. The severe racial restrictions of Louisiana's chattel society, moreover, did not preclude participation of urban enslaved blacks in the entrepreneurial economy. Frequently, if a slave benefited from an agreeable master, he or she could hire themselves out for the day in order to operate their own enterprise.

The more successful of these individuals could amass enough money to purchase themselves or their loved ones out of slavery. ${ }^{94}$ On many occasions, slaves managed to circumvent attempts to keep them from attending public balls. In one raid, fifty out of the seventy-five colored men arrested were slaves. ${ }^{95}$ In a city teeming with individuals from all walks of life, ethnicity, race, and shade of color, it became exceedingly hard to determine who belonged to which strata of society.

The first advertisement for a quadroon ball appeared in the New Orleans's Moniteur newspaper on November 23, 1805, inviting all "femmes de coule [ur] libres" and specifically excluding all "hommes de cou[ler]." ${ }^{96}$ Notwithstanding the dearth of facts concerning the balls, this simple advertisement provides more than enough food

${ }^{94}$ For more on free and enslaved black entrepreneurs see Juliet E.K. Walker, "Racism, Slavery, and Free Enterprise: Black Entrepreneurship in the United States before the Civil War," The Business History Review 60:3 (Autumn, 1986), 343-382; John Blassingame, Black New Orleans, 1860 1880 (Chicago: University of Chicago Press, 1973) ; Mary Gehman, "Visible Means of Support: Businesses, Professions, and Trades of Free People of Color," in Creole: the History and Legacy of Louisiana's Free People of Color, ed. Sybil Kein (Baton Rouge: Louisiana State University Press, 2000), 208-222.

\footnotetext{
${ }^{95}$ New Orleans Times Picayune, June 24, 1845.

${ }^{96}$ New Orleans Moniteur, November 23, 1805.
} 
for thought. What did the proprietors hope to achieve by inciting only free women of color? Why did they expressly exclude all free men of color? In a society based upon the premise of white superiority, did free men of color pose a threat to the white? While there is some dispute of when the balls were first held and by whom, we do know that as early as 1799 Don Bernard Coquet and his business partner Josef Antonio Boniquet appealed for and received rights from the New Orleans city council to hold dances open to all people - white or black. In theory, Boniquet created these dances to fund his failing theater yet the lasting legacy of these balls is one of unprecedented racial mingling and interaction, among the free and enslaved.$^{97}$ In 1800 , the city council amended Coquet's license forcing him to exclude enslaved persons. The dances, many argued, allowed too much interaction between free and enslaved and could only lead to unrest, particularly amid the wake of the Haitian revolution.

In October of 1800, Captain Juan Bautista Saraza, Pedro Tomas, Pedro Galafate and Juan Bautista Bacusa, all from the Battalion of Quadroons of the Louisiana militia, petitioned the Cabildo for weekly public dances to be held at the hall of Don Bernardo Coquet. They promised that the dances would not "interfere with the one the white people regularly have ..." In addition, the petitioners also requested guards to attend the dance so as to maintain the utmost order and tranquility. ${ }^{98}$ Shortly

${ }^{97}$ Guillory, "Some Enchanted Evening," 23-4.

${ }^{98}$ Documents of the Cabildo, accessed December 18, 2008, www.nutrias.org/exhibits/purchase/page 15 tr.htm 
thereafter, Coquet held dances every Saturday until the end of Carnival. ${ }^{99}$ These balls came to be known as the most exciting, vivacious, and colorful affairs the city could offer. Eventually, white Creoles flocked to these dances, so much so that the free colored attendees grew frustrated and resentful of their presence. Despite these initial balls and the marked commingling of whites and free people of color, it was Auguste Tessier who held the first event that can be correctly termed a "quadroon" ball. In November 1805, Tessier rented Coquet's ballroom with the intent of holding dances twice a week strictly for free women of color and white men. It is nearly impossible to ascertain Tessier's intentions, but there can be little mistaking the outcome. White men danced the nights away with free women of color and Tessier boldly offered private rooms that could be rented on a nightly, or even hourly, basis. ${ }^{100}$ Perhaps it is because of Tessier's accommodations that the quadroons began to carry the stigma of prostitutes or women of ill repute. After witnessing the popularity of Tessier's balls, Coquet followed suit by offering similar functions, as these reaped more profit than his theater performances. To avoid competition and angry clashes, an informal agreement gave Coquet Wednesday and Saturdays and the Union Ballroom threw dances on Tuesdays and Fridays. ${ }^{101}$

\footnotetext{
${ }^{99}$ Guillory, "Some Enchanted Evening," 26.

${ }^{100}$ Guillory, "Some Enchanted Evening," 27.

${ }^{101}$ Kmen, Music in New Orleans, 47-49. These dates are reinforced by the memoirs of Duke Bernhard of Saxe-Weimar who noted that the balls did indeed take place and the women who attended were just as beautiful as they were rumored to be. See William Jeronimus, trans. C.J. Jeronimus, ed. Travels by His Highness Duke Bernhard of Saxe-Weimar-Eisenach Through North America in the Years of 1825 and 1826 (University Press of America, Inc.: New York, 2001), 343.
} 
The women who attended the balls, all descendents to some degree of a

European white male and African or Indian female, collectively became known as quadroons, regardless of their actual percentage of European blood, ranging in various shades of skin and eye color. Travel journals of visitors from abroad almost unfailingly remark upon the beauty of the quadroons and the peculiarity of the entire population. While the populace, prior to American occupation, was not large, it was undeniably attractive and successful. ${ }^{102}$

Color gradations within the community of Creoles of color were fiercely protected and of paramount importance to a community who took every step possible to distance itself from its "darker," African heritage. Privileges, money, and a perceived degree of respectability all came with a closer association with the ruling class. Historian and traveler Frederick Law Olmsted recorded the gradations, as accepted during the midnineteenth century:

Sacatra - the child of a griffe and a negress

Griffe - the child of a negro and mulatto

Marabon - the child of a mulatto and griffe

Mulatto - the child of a white and a negro

Quateron - the child of a white and a mulatto

Metif - the child of a white and quarteron

Meamelouc - the child of a white and a metif

Quarteron - the child of a white and a meamelouc

Sang-mele - the child of a white and a quarteron ${ }^{103}$

${ }^{102}$ There is no concrete evidence that Miro's law is the direct result of pressure from white women, however many historians, myself included, believe that it is quite likely that Miro passed his law due to such pressure. Marcus Christian firmly believes that white women instigated the law as it was during this decade that miscegenation rapidly increased. Marcus Christian Collection, MSS 11, Box 14, Folder 1 "The Creoles of Louisiana, White Men and Negro Women." Earl K. Long Library, University of New Orleans, New Orleans, Louisiana.

${ }^{103}$ Frederick Law Olmstead, Journey in the Seaboard Slave States with Remarks on Their Economy (New York: Dix and Edwards, 1856), 583. 
In such a hierarchy, the qauarteron [sic] looked down upon the meamelouc, just as the meamelous looked down upone [sic] the metif, and so on. Those referred to as "Negro," whether free or enslaved, could claim no white but primarily pure African ancestry. Furthermore, within the free colored community how one acquired their independence created an additional difference in status. Ironically, among the free black community (men and women recently manumitted) those who bought their freedom were regarded as thrifty, prudent, and independent; one might say better than those individuals who acquired their freedom via blood relationships with the white community. ${ }^{104}$ Nevertheless, such a distinction must not have had a profound impact on the community as the quadroon balls reached their apex in the mid-nineteenth century and plaçage relationships remained popular.

The respectability of quadroon balls varied as much as the skin colors of the women who attended. Some dances threw their doors open to anyone who could afford the fifty-cent ticket fee while others charged an exorbitant two dollars in order to cull out the lower-class men in favor of wealthy Creole gentlemen. The dances that commanded the highest ticket price and touted the chastest Quadroons catered to the upper class, wealthiest tier of European and Creole society. The quadroons, whether male or female, often elicited comments about their striking beauty, intelligence, and flawless manners. Many of them came from brilliant, comprehensive educations and traced their lineage to some of the finest Creole families in Louisiana.

104 Marcus Christian Collection, MSS 11, Box 13, Folder "Genealogy, The Beginnings of the Free Colored Class.” Earl K. Long Library, University of New Orleans, New Orleans, Louisiana. 
Eliza Potter, a free woman of color and successful hairdresser to both white and colored Creoles, described one such hostess as "tall, fine looking ... who looked as though she might be white, but a little sunburnt." She was "dressed in white silk, with a head-dress of crimson, a full set of coral." Her father was a "pure white creole, her mother a colored creole, a brown skinned woman; she was dressed in black silk, with a full set of white lawn." ${ }^{105}$ The other women who participated in the soiree, according to Potter, were equally beautiful and elegantly dressed. Potter noted "a most beautiful brown skinned woman, elegantly dressed in pink brocade, and a full set of diamonds; she was led in by the Spanish ambassador." Potter thought her to be "more like an African princess than a Louisiana Creole." 106

Potter was certainly not the only woman struck by the quadroons' beauty. Travel writer Eleanor Early, one of the most thoughtful visitors to New Orleans, wrote that the most beautiful woman she had even seen came from a unique mix of ancestry; married to a diplomat from Haiti, this woman possessed "skin like gardenias," and hailed from the great French Dumas family, part of which was white and the other mulatto. Her ancestral link to the Dumas family had been the son of a French marquis and a colored woman from Santo Domingo. ${ }^{107}$ As for the quadroons of New Orleans, she believed that there never existed a more beautiful yet notorious and hated group of women. White Creole women detested quadroons to such an extent that the Duke of

\footnotetext{
${ }^{105}$ Potter, A Hairdresser's Experience, 190-192.

${ }^{106}$ Potter, A Hairdresser's Experience, 190-192.

${ }^{107}$ Eleanor Early, New Orleans Holiday (New York: Rinehart and Company Inc., 1947), 185.
} 
Saxe-Weimar pitied the quadroon due to the "prideful, arrogant, [and] scornful ... language with which the Quadroons are addressed by the female Creoles ..." Another unnamed observer noted that, "If it be known that a stranger, who has pretensions to mix with good society, frequents such balls as these, he may rely upon a cold reception from the [white] ladies." ${ }^{108}$ The Creole gentlemen, remarked the Duke Bernhard, "do not remain long at the ball but proceed instead to a so-called Quadroon ball, where they enjoy themselves more and are not so shy."109

White Creole gentlemen may have felt more unrestrained at the quadroon balls, yet the Duke unwittingly defends the honor of the mixed Creole ladies."To remove all semblance of vulgarity from these balls," he noted, "they set an admission fee of two dollars, thereby allowing only gentlemen of the higher class to attend. . I must confess that I found this ball much more decent that the [white] masked-ball. The coloured [sic] ladies were under the scrutiny of their mothers, they were properly and elegantly dressed and conducted themselves with proper manners and great modesty. . . I could not help but make a comparison [sic], however, and this comparisson [sic] did not come out favourable [sic] to the white-ball." ${ }^{110}$ A New York reporter, according to Eleanor Early, attended a white ball at the French Opera House and found that "there were very few men there and too many women. The ladies ... were dull, fat, and badly rouged." The quadroons, on the other hand, "conducted themselves with

\footnotetext{
${ }^{108}$ Guillory, "Some Enchanted Evening," 32.

${ }^{109}$ Jeronimus, Travels By His Highness Duke Bernhard of Saxe-Weimar-Eisenach, 343.

${ }^{110}$ Jeronimus, Travels By His Highness Duke Bernhard of Saxe-Weimar-Eisenach, 346-347.
} 
equal propriety and modesty. Moreover, they were beautiful to look upon. They were gracefully gowned, their smiles came and went with their talk, and they captivated all who were present." ${ }^{\text {111 }}$ Not only did the quadroon balls present serious competition for the white balls, but the women themselves posed a formidable threat to white women, and thus the institution of white marriage. Several white men chose to remain lifelong bachelors and eschew traditional marriage in favor of keeping a quadroon companion. Even as late as 1947 , Early noted that white women still bristled at their memory.

The lovely quadroon carried herself with grace and dignity, despite her precarious social position. Many, mostly the male children, traveled to Paris to be educated and proved themselves as capable as whites when it came to learning, refinement, and culture. ${ }^{112}$ This population, according to author Sir Charles Lyell, "return with refined manners, and not infrequently with more cultivated minds that the majority of those from whose society they are shut out." ${ }^{\text {113 }}$ The Duke Bernhard also

${ }^{111}$ Early, New Orleans Holiday, 191.

${ }^{112}$ The first recorded occurrence of a mulatto son being sent to France by his white father is Jacques Coustillon in 1739. There are numerous cases of New Orleans Creole expatriates distinguishing themselves in French society: four of the most prominent are the engineer Norbert Rillieux, the poet Camille Thierry, and composer Edmond Dédé. Rillieux, the son of a French engineer and the quadroon Constance Vivant, is credited with the invention of the first triple-effect evaporator that revolutionized the sugar industry by increasing sugar granulation and reducing costs. Thierry, the son of a wealthy French businessman and an octoroon, became one of the preeminent poets of his time. Fourteen of his poems appear in Les Cenelles, a compilation of poetry written entirely by men of color, more than any other poet. Dédé belonged to a family that emigrated from St. Domingue. He is credited as writing the first piece of music ever published by a free man of color. For more on the career of these three men see Michel Fabre "New Orleans Creole Expatriates in France: Romance and Reality," in Creole: The History and Legacy of Louisiana's Free People of Color, Sybil Kein, ed. Baton Rouge: Louisiana State University Press, 179-195.

${ }^{113}$ Sir Charles Lyell, A Second Visit to the United States of North America Vol. II (New York: Harper \& Brothers, 1849) 94. 
thought it important to note that many of the female Creoles of color "enjoy a much better education than many of the whites, normally conduct themselves with better manners and morales [sic], and often make their friends much happier than white ladies make their husbands."114

The belles of the balls ranged in color and shade like pebbles in a creek. Collectively they all became known as quadroons; however, that designation is, technically speaking, erroneous. The racial lines could be so finely drawn than the untrained eye could easily mistake a Creole Spanish lady for one of the fabled quadroons. The architect John H.B. Latrobe recalled an occasion when in New Orleans he commented to a local about a beautiful Spanish woman. The local, startled, informed Latrobe that the Spanish lady was no Spanish lady at all, but in fact she was a mulatto. "I'll know better next time," Latrobe commented. In his next attempt at identifying mulattos and Creoles, Latrobe pointed to a group of women asking, "Are those quadroons on high there, in the balcony ... One of them has a veil, and all that I see are darker than she [the mulatto] we have just passed." "Heavens no," replied the patient local, "they are creoles — natives, whites - Spaniards and French mixed born in the country — very good society."115

There is little in Latrobe's journal that might be construed as condoning the interracial relationships between Creole gentlemen and women on color. Unlike the

${ }^{114}$ Jeronimus, Travels By His Highness Duke Bernhard of Saxe-Weimar-Eisenach, 347.

${ }^{115}$ Samuel Wilson, Jr., ed. Southern Travels: Journal of John H.B. Latrobe, 1834. (New Orleans: the Historic New Orleans Collection, 1986), 43. 
women in white society, however, Latrobe places the blame squarely on the strapping shoulders of the Creole gentlemen and pities "the poor creatures whom the white man's sins make infamous." 116 He seems to sympathize with the quadroon and is utterly horrified that the white gentlemen allowed their natural daughters to follow in their mothers' footsteps. The balls, Eleanor Early scathingly reported, were little more that a "frank and elegant sex mart where Creole bluebloods chose their mistresses with taste and decorum." 117

Harriet Martineau shared Latrobe's point of view on the practice of sanctioned miscegenation. In one of her social commentaries, Martineau, a fastidious observer, lamented that the quadroon girls were "brought up by their mothers to be what they have been; the mistresses of white gentlemen."118 Latrobe and Martineau's evaluation is understandable; nevertheless, such a summation strips the women of any independent agency. Martineau's fatalistic view assumes that every quadroon followed blindly in predetermined steps, essentially forced by their mothers to become placeés. Out of this portrayal popular the pervasive image of the "tragic mulatto" was born.

American abolitionists found the perfect symbol for their cause in the tragic mulatto. Trapped somewhere between black and white, denied the "legitimacy of whiteness and the communal support of blackness," the mulatto represented a sad

\footnotetext{
${ }^{116}$ Wilson, Southern Travels, 80.

${ }^{117}$ Early, New Orleans Holiday, 198.

${ }^{118}$ Harriet Martineau, Society in America (New York: Saunders and Otley, 1837), 116-117.
} 
creature who succumbed to unrequited love. ${ }^{119}$ Always beautiful and of faultless morals, she attempted, and always failed, to hide her African ancestry. In many cases the tragic mulatto falls in love with a white man only to lose him (despite being the ideal woman) once her "shameful" ancestry is revealed. Abolitionists encouraged this representation to illustrate how the tragic mulatto fell victim to the horrors of miscegenation.

Although white men exploited women of color, the life of many quadroons should not always been assumed to have been tragic or heartbreaking. Quadroons, like the celebrated European courtesans, could acquire a good deal of money, jewels, and property. Women of color exercised an astonishing amount of self-determination given the mores of the paternalistic antebellum period, as evidenced by their numbers involved in trade, mercantilism, and even slave trading. Indeed, several of these women claimed a tidy fortune and exhibited sharp business acumen. Although such wealth usually served as the exception and not the rule, the record demonstrates that many of those who did acquire property or money managed it well, turned a tidy profit, and lived comfortably. ${ }^{120}$ The home of a comfortable quadroon may have been

${ }^{119}$ Guillory, "Some Enchanted Evening," 149-150.

${ }^{120}$ For example, Madame Cecee McCarty owned thirty-two slaves and by 1848 was worth more than $\$ 155,000$. Eulalie Mandeville claimed an estate in excess of $\$ 155,000$, including several pieces of property, a dry goods business, and several slaves. According to Marcus Christian, free women of color owned, on average, twice the amount of property as did free men of their own class. Marcus Christian Collection, MSS 11, Box 14, Folder 1 "The Creoles of Louisiana, White Men and Negro Women." Earl K. Long Library, University of New Orleans, New Orleans, Louisiana. See Juliet E. K. Walker, "Racism, Slavery, and Free Enterprise: Black Entrepreneurship in the United States before the Civil War," The Business History Review 60:3 (Autumn, 1986), 343-382 and Macarty et al $v$. Mandeville Supreme Court of Louisiana, New Orleans 3 La. Ann. 239; 1848 La. Lexis 128. 
"unimpressive," yet usually consisted of slaves, cooks, maids, errand-boys and even hairdressers to assist in grooming and attire. ${ }^{121}$

The clothing and appearance of quadroons provided a popular and colorful subject for those new to New Orleans. Visitor Joseph Holt Ingraham left one of the most vibrant and vivid of these descriptions to us, circa 1856:

Direct in front of me sat a handsome yellow "lady," her head surmounted by an orange and scarlet plaid handkerchief, bound about it Turkish-turban fashion; a style that prevails here among Creole servants... upon her neck was a richly worked black lace scarf; her dress was plain colored silk made in the most costliest manner. Her olive hands, which had very tapering fingers and remarkable oval nails, were covered with rings, chiefly plain gold ones. In one hand, she held a handsome parasol and in the other fondled a snow white French poddle upon her lap, said poodle having the tips of its ears tied with knots of pink ribbon, and a collar of pink silk quilled, and made like a ruff, while the end of its tail was adorned with a bow of blue ribbon, in the tastiest of styles; and as if his poodleship were not sufficiently decorated to be taken to the city to visit his town cousins, it had a nice bow of red satin tied about each of its four ankles. ${ }^{122}$

The New Orleans's Daily Picayune from August 21, 1838 also provided an illustrative example of a quadroon fashion plate of the period:

A handsome Quadroon, was attired, as well as we could make out, in the following dress...one white stain gown, neatly made and decorated with flounces, cut and fringed, and broad hems in the skirt, one crimson belt or zone, one pink neck handkerchief, one pair blue hose, one pair white stain shoes, with large shining buckles and a profusion of bows, ribbon, and braid, on large bunch of artificial flowers in her [hair], one black veil, one yellow pocket handkerchief, one green umbrella with brown border with lilac fringe.

${ }^{121}$ Early, New Orleans Holiday, 187.

${ }^{122}$ Ingraham, 330. 
The quadroons' beauty served as both a gift and a curse. From the earliest days of the colony, white Creole women resented the presence of their Creole counterparts of color. Their mere existence served as a constant reminder of the Creole gentlemen's youthful indulgences or philandering, as the case might be. The dimples, smile, or other physical features of a light skinned child who frolicked in the streets trailing behind a white-gloved quadroon could trip a sense of recognition in a Creole woman reminiscent of a husband or son. Most women chose to turn a blind eye, as it was the path of least resistance. Others simply ignored the possibilities. "Every white lady," wrote Martineu, "believes that her husband has been an exception to the rule of seduction." ${ }^{123}$ Legally speaking, a white woman could have an offending quadroon flogged, but few tried. Such actions only earned the wrath of an angry husband. Those who did attempt to chastise their husbands or sons risked anger or fierce retribution. In a strongly patriarchal society such as that of Louisiana, a Creole gentleman and family head was free to exercise his iron fist. As a result, many Creole wives opted to suffer in silence and bear the disgrace as proudly as possible.

One woman, however, appeared to act on her anger and resentment: Madame Delphine Macarty Lalaurie. A perfect paragon of Creole society, Madame Lalaurie excelled at business, was beautiful, intelligent, wealthy, a practicing Catholic, and what is more, particularly powerful for a woman. Nevertheless, she proved to be cruel and sadistic, prompting Harriet Martineau to comment that New Orleans was, "the last

\footnotetext{
${ }^{123}$ Martineau, Society in America, 117.
} 
place in which men are gathered together where one who prizes his humanity would wish to live." 124 Lalaurie had chained several slaves in her upstairs attic, performing brutal experimentations on them. It was not until one of her slaves lit the house on fire that her deeds were discovered. There is little to excuse Delphine Lalaurie's vicious treatment of her slaves, however, historian Katy Morlas suggested that the unique racial environment in which Lalaurie was born helps to explain her actions.

Madame Lalaurie descended from one of the most distinguished families in Louisiana, the Macarty family. What is important to note is that she belonged to one of two branches of the Macarty family, one being white and the other being free and of color, both considerably wealthy. In a city the size of New Orleans it would have been nearly impossible for Delphine to be ignorant of her colored relatives, particularly since many of them were lawyers, slaveholders, business operators, and plantation owners. Eugene Macarty, Delphine's uncle, considered Eulalie Mandeville, a free woman of color, his wife. ${ }^{125}$ Furthermore, according to Morlas, there is a fair amount of documentation that suggests Delphine's own father had a relationship of undetermined length with a free woman of color. Morlas believes that it was just not the Creoles of color, but everyone of African descent, that Delphine hated. ${ }^{126}$ As

${ }^{124}$ Martineau, Society in America, 276. For a more in-depth discussion of Madame Lalaurie see Fred R. Darkis, Jr. "Madame Lalaurie of New Orleans," Louisiana History 23:4 (Fall 1982).

${ }^{125}$ Macarty et al v. Mandeville. The relationship between Eugene and Eulalie will be more thoroughly explored in the following chapter.

${ }^{126}$ Katy Frances Morlas, "La Madame Et La Mademoiselle: Creole Women in Louisiana, 1718-1865," (MA thesis, Louisiana State University, 2005), 120-128. 
George Washington Cable wrote, Delphine "hated - as only woman can hate enemies of the hearthstone. .."127

As the free colored Macartys prospered in Delphine's city, an overriding fury seemed to drive her to such horrific treatment of her own slaves. Delphine was by no means the only cruel slave owner in Louisiana. According to Benjamin H. Latrobe, the general opinion of local masters and mistresses "is that the Americans treat and feed and clothe their slaves well, but that the creoles are, in all these respects, comparatively cruel." He could barely see how the "fair, mild, and somewhat languid faces [of the white Creole women] could express any feeling but of kindness and humanity. And yet several, I had almost said many, of these soft beauties had ... handled the cowskin with a sort of savage pleasure, and those soft eyes had looked on the tortures of their slaves, inflicted by their orders, with satisfaction ... which should stop short of the life of their property." ${ }^{28}$ In Delphine's case, her resentment appeared to be rooted in the belief that she was a victim of plaçage. Not able to openly attack a free person of color without cause, Delphine seemed to take out her anger on her own slaves. In the end she fled the city she loved, losing her social standing, money, business, and home.

Another attack on plaçage emanated from Spanish Governor Esteban Rodriguez Miró. Believing that the free female Creole population was becoming too

${ }^{127}$ George Washington Cable, "'The Haunted House' in Royal Street," in Strange True Stories of Louisiana. (New York: Charles Scribner's Sons, 1901), 201.

${ }^{128}$ Benjamin Henry Latrobe, The Journal of Latrobe: Being the Notes and Sketches of an Architect, Naturalist, and Traveler in the United States from 1796-1820 (New York: D. Appleton and Company, 1905), 182. 
disruptive in its behavior and a threat to social order, colonial political and religious authorities decided to act. This sumptuary law of 1786, put forth in Miró's bando de buen gobierno, or edict of good government, came to be known as the tignon law. This statute required free women of color to wear a tignon, or head wrap, whenever in public. Specifically, it forbade quadroons to wear feather plumes, jewels, and other dressings in their hair. Miró, like most Europeans of the time, believed that clothing signified class and status. In other Spanish colonies, in fact, colonial legislation forbade women of color to wear silk, gold, silver, or pearl jewelry. ${ }^{129}$ Lastly and largely in vain, Miró entreated the women to "renounce their mode of living, and to betake themselves to honest labor." Any excessive attention to dress would be considered "evidence of their misconduct." ${ }^{\text {130 }}$ Wearing the tignon meant compliance with Miro's law but also a new avenue of expression for a community.

Forcing free women of color to wear the tignon sent a clear message to the free population of color. Miró wanted to remind the community of their tenuous position with the social hierarchy of Louisiana. In a society where it was increasingly difficult to discern one's ethnicity, the wearing of the tignon acted as a virtual brand-a means by which one could clearly identify the racial status of women who could have very easily otherwise passed for white. The tignon also served to identify the free colored women with their enslaved sisters who wore a similar head wrap. According to

${ }^{129}$ Meacham Gould, "In Full Enjoyment of Their Liberty," 195.

${ }^{130}$ Charles Gayarré, History of Louisiana: The Spanish Domination vol. III $3^{\text {rd }}$ edition (New Orleans: Armand Hawkins, 1885), 179. 
historian Virginia Meacham Gould, "Free women of color who had become too light skinned or too clean or who dressed too elegantly, or who, in reality, competed too freely with white women and thus threatened the social order, were to express their ties to slavery through a simple head kerchief."131

The Spanish government hoped that the tignon would make the quadroons less appealing to white men, thus restoring the social balance. Conversely WPA historian Marcus Christian argues that the status of the free colored Creole lovers was only a step below that of white wives and sweethearts despite legal mandates. Due to the wealth and influence of their "protectors," many of the quadroons did not have to work as they more often than not had slaves to do the majority of the labor. ${ }^{132}$ "The more popular became the concubinage of mixed-blood women by white men," wrote Christian, the less the occurrence of marriages between white men and white women. "This meant a general enrichment of the free colored group at the expense of the dominant white group." ${ }^{\prime 33}$ The law of 1786 provides evidence that the white majority was becoming threatened by the independence, social security, and accumulated wealth of the free Creole population of color, more specifically its women.

Despite the requirement of tignons, free women of color attempted to distance themselves from the slave population whenever possible. They sought close proximity

${ }^{131}$ Meacham Gould, 196-7.

${ }^{132}$ Marcus Christian Collection, MSS 11, Box 14, Folder 1 "The Creoles of Louisiana, White Men and Negro Women." Earl K. Long Library, University of New Orleans, New Orleans, Louisiana.

${ }^{133}$ Marcus Christian Collection, MSS 11, Box 14, Folder 1 "The Creoles of Louisiana, White Men and Negro Women." Earl K. Long Library, University of New Orleans, New Orleans, Louisiana. 
to white society, and if the way was barred, found solace in their own free colored population. At no time did they identify with the enslaved blacks. Free status meant an automatic elevation above slaves. That said, why did so many quadroons allow themselves to be painted or represented wearing the tignon, a clear link to slavery? Did they symbolically reclaim the tignon as a matter of cultural pride?

Refusing to be cowed by the law, as white Creole women had hoped, the tignon became not only a fashion statement, but also one of community and identity. "The bright reds, blues, and yellows of the scarves, and the imaginative wrapping techniques employed by their wearers, are said to have enhanced the beauty of the women of color," one historian has concluded. ${ }^{134}$ Author Helen Bradley Griebel argues that the head wrap functioned as a "'uniform of rebellion,' signifying absolute resistance to the loss of self-definition." 135 The tignon became a defining accessory of the quadroon; one that represented their freedom, history, and power. Ironically, the tignon morphed from a functional headpiece into a sign of empowerment.

The use of clothing as a medium of expression for people of color has a long history. Shane White and Graham White's masterpiece, Stylin' African American Expressive Culture from Its Beginnings to the Zoot Suit, chronicles the long love affair

${ }^{134}$ Carolyn Morrow Long, A New Orleans Voudou Priestess: The Legend and Reality of Marie Laveau. (Gainsville: University of Florida Press, 2006), 21. Marcus Christian postulates that Governor Miro's law, in which he also reiterated the illegality of concubinage, was only in effect in the city of New Orleans as it appears that a legal marriage occurred between a white man and a quadroon woman at Natchez. Marcus Christian Collection, MSS 11, Box 14, Folder 1 "The Creoles of Louisiana, White Men and Negro Women." Earl K. Long Library, University of New Orleans, New Orleans, Louisiana.

${ }^{135}$ Helen Bradley Griebel, "The African American Woman's Headwrap: Unwinding the Symbols," accessed August 21, 2008, http://char.txa.cornell.edu/Griebel.htm 
between Africans and their clothing. According to White and White, newly arrived slaves to North America were clothed in European fashion and forced to conform to the "European concepts of decency."136 This meant that they quickly had to adapt to European fabrics and mandates about style and clothing. It is obvious by the proscriptions on slave clothing that clothing was meant to be one way of signifying one's status, without relying solely on skin color or ethnicity.

The South Carolina Negro Act of 1735 proved to be unenforceable largely due to white indifference, but more significantly due to the determination of the slaves not to be conform to it. Sumptuary laws, much like those against miscegenation, went unheeded except in times of uncertainty or anxiety, when the white slaveholding class felt threatened by the slave population. In fact, most slaves inherited their clothing from their masters. While there are certainly no field guides to the way eighteenthcentury slaves looked, one source for examining slave culture and dress are the thousands of runaway advertisements printed in both northern and southern colonies. These sources reveal a wide range and variety of slave clothing and accoutrements. White and White explain that "through the ways they fashioned their appearance, African and African American slaves discovered an often surprising degree of social and cultural space." 137 Some slaves amassed fairly large wardrobes and took great pride in the ways in which they dressed.

${ }^{136}$ Shane White and Graham White, Stylin' African American Expressive Culture from Its Beginnings to the Zoot Suit (Ithaca: Cornell University Press), 1998, 6.

${ }^{137}$ White and White, Stylin', 10. 
The tignon arrived in Louisiana from the French colonies of Martinique and St. Domingue. Creole women in Martinique wore elaborate head wraps called tetes that were commonly made of brightly colored madras cotton. Dominique Cocuzza of the Fashion Institute of Technology explained that the act of wrapping the head traditionally carried several layers of meaning, particularly in the black community. ${ }^{138}$ Head wraps could convey a woman's occupation, her social status, religious concepts, and social affiliations. Bold colors such as red, yellow, green, and white were often used in voodoo to signify particular religious concepts; the way a woman tied the knot in her head wrap also acted as a symbolic form of protection associated with voodoo. ${ }^{139}$ In New Orleans, voodoo was, and remains, a very female oriented and led religion. Aside from symbolic representation, the tignon offered practical benefits as well. Tignons were used to cover undone hair or to preserve elaborate hairstyles. The wrap kept the hair clean, absorbed perspiration, and protected from the sun. As a result, the tignon was a practical and necessary accoutrement for slave women, as well as a convenient social marker in a slave society, one that would, conceivably, offend a free woman of color to wear.

Miró's law attempted to diminish the shining beauty of New Orleans' quadroons. However, in a gesture that is symbolic of the entire community of free people of color, quadroon women accepted Miró's law and adapted to the

${ }^{138}$ Dominique Cocuzza, "The Dress of Free Women of Color in New Orleans, 1780-1840," Dress 27 (78-87, 2000), 4.

${ }^{139}$ Barbara Trevigne quoted in Cocuzza, "Teh Dress of Free Women of Color," 4. 
circumstances. Instead of tarnishing their beauty, the tignon, worn high off the forehead, framing the face in a most regal manner, only made the quadroon woman appear more exotic, and thus attractive, to white males. ${ }^{140}$ The tignon enhanced the quadroon's already striking beauty. All the ornaments forbidden by the law migrated to the tignon. Flowers, ribbons, jewels, and feathers bedecked the quadroons' head wraps. Those who could afford it used the finest silks and fabrics from Europe. By 1837 one could see Creole women wearing tall, towering head wraps made of the finest material found, adorned with feathers, jewels, and bright colors. ${ }^{141}$ The more embellishments and the longer the length of cloth signified the higher status of the wearer. Similarly to their African ancestors, these women prided themselves on their elaborate head wraps, intricate patterns, and knots. New Orleans's quadroons reinterpreted the law without explicitly breaking it. In an interesting turn of events, even some white women adopted the madras tignon.

Wearing the tignon did not humiliate the quadroons as hoped. They wore their head wraps with pride, as a sign of their community. Although this unique and distinct community worked carefully to distance itself from its African ancestry and to closely align with the white ruling class it firmly understood its tenuous position as a third caste in the social structure of the Gulf South. Quadroon women were neither black nor white, therefore, they had to forge their identities not as white and not as black, but

${ }^{140}$ Lillian Crete, Daily Life in Louisiana, $1815-1830$ trans. Patrick Gregory (Baton Rouge: Louisiana State University Press, 1981), 81.

${ }^{141}$ Cocuzza, "The Dress of Free Women of Color," 4. 
as a Creole of color. This meant that the same principles, morals, and rules of white or enslaved society could not be equally applied to this population. Therefore, quadroon women adapted when necessary. The tignon is one example of this adaptation, as is the practice of plaçage. Out of this struggle for self-definition and survival emerged a romanticized, often distorted history of Creole women of color.

Stripping away all the layers of the myth and carefully examining the intricately embroidered stories surrounding the quadroons and their balls, we find a group of women who exercised a considerable amount of agency and selfdetermination. In the hazy ground between black and white, free Creoles of color crafted an existence and a community that they carefully guarded. Women of color were forced to create an identity within a society shaped by slavery, and accordingly tended to conform to as many of the norms of white society as possible. To abolish slavery meant to eliminate the caste of free people of color. In many ways, in fact, the free community depended on its close ties with white society and therefore, found it in their interest to uphold the system of slavery. Therefore, they clearly did not identify with black, enslaved women. Eliza Potter noted that color made no difference; "the most tyrannical, overbearing, cruel taskmistress that ever existed" was a free woman of color named Kate Parker. Parker allegedly "nearly beat her slave to death with cowhide." 142 It seems, then, that it would be erroneous to assign women of color to the role of helpless, passive victims. On the contrary, the quadroons of New Orleans

${ }^{142}$ Potter, A Hairdresser's Experience," 159. 
understood that they were neither white nor black, but something wholly altogether different. With this understanding they struggled against marginality and defamation. In one sense, the balls could be viewed as a celebration of their unique position, diversity, and position.

The dances, Guillory argued, were little more than glorified slave marts, but I disagree. She does, however, acknowledge that that the draw of the quadroon was three-fold: the balls incorporated religion, deeply embedded roots of French culture, and the unique tri-color racial hierarchy of New Orleans. ${ }^{143}$ The absence of Puritanical influence allowed for a vibrant dance tradition to blossom, unlike the Puritan strongholds up the Atlantic seaboard. Add to this the frontier mentality of early Louisiana society and it is easy to understand how quadroon balls, plaçage, and such a large population of free people of color developed and thrived.

The quadroon balls were a logical outgrowth of the vital dance tradition in New Orleans and are only one facet of the fascinating multi-cultural milieu where French, Spanish, American, Indian, and African Americans interacted on a daily basis. In a society that forbade interracial marriages there were few options for men who wished to engage a woman of color, or vice versa. If, in fact, they had been allowed to marry, we can only surmise what the rate of marriage might have been. Equating the balls to slave markets and the women to prostitutes reinforces the paradigm of black and white, and does not allow for the creation of a new model, that of a society of white, black, and something in between. Such pronouncements underpin the theory 
that things must be, literally and figuratively, black or white. Yet the free population of color successfully challenged this model, leading to contradictions and exceptions in New Orleans's unique culture. 


\section{Chapter Three \\ "the objects of choice and affection." \\ Plaçage and Family}

"The sin is his, far more than hers."

John H.B. Latrobe

In the nineteenth century, white men dictated virtually all rules and conditions surrounding sexual relations. So when white men began choosing to form lasting relationships with free women of African descent instead of white women, turning accepted sexual practices on their head, the moral and social watchdogs leaped at the opportunity to roundly condemn those involved. Slavery apologists and abolitionists argued that the women involved were no more than mere victims who had no other choice but to surrender to white ascendancy. Spurned white women explained away such preferences by blaming the relationships on the seductive, beguiling charms of the African race. Historians, on the other hand, attributed miscegenation to two reasons; the first being a shortage of acceptable white women and the second being the immoral behavior of undisciplined slave owners. In respect to the majority of sexual encounters between slave and master, the latter is probably true, however when discussing miscegenation between white males and free women of color it might be said that, "White girls often had less choice in picking a husband than Quadroons did in choosing a lover."

Not all relationships between white Creole gentlemen and women of color can be classified as plaçage. The term refers strictly to relationships in which a young

\footnotetext{
${ }^{144}$ Early, New Orleans Holiday, 199.
} 
woman, termed the placeé, bound herself to a white man, known as the placer, involving a contract and terms agreed upon by both parties. During his visit to New Orleans, the architect Frederick Law Olmstead noted that, "Of course, men are attracted by them [quadroons], associate with them, are captivated, and become attached to them, and, not being able to marry them legally, and with the usual forms and securities for constancy, make such arrangements as can be agreed upon." "When a man makes a declaration of love to a girl of this class, she will admit or deny, as the case may be, her happiness in receiving it; but supposing she is favorably disposed, she will usually refer the applicant to her mother." The mother then inquires "like a Countess of Kew," into the finances and situation of the suitor until she is satisfied that he can provide for her daughter in a manner in which she was accustomed to living. It was imperative that any possible suitor be able to provide not only for his placeé but also for any resulting children. The contract stipulated a home for the young woman and frequently also included a household staff, budget, and furniture. Most importantly, most contracts predetermined a severance amount to provide for the placeé should either party decide to terminate the relationship. Love, remarked Olmstead, "is sedulously restrained, and held firmly in hand, until the road . . . is seen to be clear." Such contracts possibly provided the best means of security for a young woman with few options in a patriarchal slave society where freedom often proved tenuous at best. ${ }^{145}$

\footnotetext{
${ }^{145}$ Frederick Law Olmstead Journey in the Seaboard Slave States, with Remarks on Their Economy (New York: Dix and Edwards, 1856), 594-595.
} 
Historian Peggy Pasco argues that miscegenation and interracial marriage (or pseudo marriage) should not be viewed as exceptional or deviant, when in fact it is something that comes quite naturally. ${ }^{146}$ The argument that all women who were involved with white men did so out of sheer necessity is erroneous, yet on the other hand, it would be equally wrong to deny that many women of color did make such alliances with the hopes of finding some measure of security. Assuming that all women of color engaged with white men clung to them out of financial necessity would discount the many cases of free women of color who maintained jobs and ran successful businesses on their own. Those supported by white benefactors clearly held an advantage over those who did not; however, many women independently entered into business ventures using only their own capital. The occupations of these enterprising women varied greatly from those as laundresses, seamstresses, domestics, and cooks to plantation mistresses, marchandes, and tradeswomen. Others owned bakeries, hairdressing shops, and coffee houses. ${ }^{147}$ They peddled their own wares and merchandise in the streets and stalls of the Vieux Carré. In many cases, free women of color "owned more property than did either free men of color or white women." 148

${ }^{146}$ Peggy Pascoe, What Comes Naturally: Miscegenation Law and the Making of Race in America (Oxford: Oxford University Press, 2009). In her text, Pasco focuses on miscegenation primarily in the American West and Southwest; however her theory concerning miscegenation is applicable to black/white miscegenation as well.

${ }^{147}$ Loren Schweninger, "Property-Owning Free African American Women in the South, 1800 1870," Journal of Women's History, 1:3 (Winter, 1990), 17.

${ }^{148}$ Virginia Meacham Gould, "Henriette Delille, Free Women of Color, and Catholicism in Antebellum New Orleans, 1727-1852," in Beyond Bondage: Free Women of Color in the Americas, ed. David Barry Gaspar and Darlene Clark Hine, (Urbana: University of Illinois Press, 2004), 273. 
Boarding house and hotel ownership proved to be one of the more successful business ventures for free women of color in New Orleans and the Lower South. Lucy Ann Cheatham, Elizabeth Reid, Mary Harby, and Martha Johnson all owned and operated successful and accommodating boarding houses in New Orleans. The average estate of each of these women totaled nearly eighteen hundred dollars. ${ }^{149}$ "As landladies," noted Louisiana historian Charles Gayarré, "the quadroons were always affable and anxious to please. A cross one would have been almost a phenomenon. They were intent on guessing at your wants, on anticipating your wishes, and showing their pearly teeth through smiling lips. As women they were generally attractive in their persons, and some very handsome. If the tenants of their furnished rooms felt sick, the old quadroons, and under their direction the young ones, were the best and kindest of nurses." In a moment of high praise, Gayarré noted that, "As to their honesty it was proverbial." 150

In the rural Lower South, explained historian Loren Schweninger, a small number of free women of color rose to the rank of plantation master. Due to a direct link to the white planter class, these female planters either inherited their estates from a father, lover, or other white benefactor. Despite their good fortune, it took much more than luck to run a profitable operation; it required financial solvency, shrewd business acumen, and hard work. To own any successful business took more than an inheritance or gift from a lover.

18.

${ }^{149}$ Schweninger, "Property-Owning Free African American Women in the South, 1800-1870," ${ }^{150}$ Gayarré, "Historical Sketch," 9. 
One of the most successful examples of an independent female plantation owner is Margaret Mitchell Harris of South Carolina. Harris inherited her plantation not from a white placer or paramour, but from her mulatto father, himself the son of a white planter. In addition, Harris inherited the twenty-one slaves and entire household from her father. In the year 1849, Harris' plantation produced an astonishing 240,000 pounds of rice. Louisiana offers several examples of independent female planters: sugar planter Louise Oliver of Plaquemines Parish; Madam Cyprien Ricard, a slave owner of Iberville Parish; planter Marie Suzanne Metoyer of Natchitoches Parish; plantation owner Louisa Ponis of St. John the Baptist; and Agnes Mahier, a slave owner from Baton Rouge. ${ }^{151}$ These free women formed a respectable and prosperous group of businesswomen and in some cases, rivaled even their white, male equivalents. $^{152}$

According to the US census of 1850 , free women of color owned real estate estimated at $\$ 2,033,500$; by 1860 they owned $\$ 2,782,700$ worth of the total $\$ 12,807,100$ owned by blacks. These women, on average, owned slightly more property and controlled more wealth than black males; certainly they independently possessed more wealth, property, and freedom than their white female

${ }^{151}$ Schweninger, "Property-Owning Free African American Women," 18.

${ }^{152}$ Much like white plantation owners, these women bought, sold, and traded slaves to turn a profit and provide a labor force. Despite their shared ancestry and struggles as women in a slave society, colored masters demanded just as much out of their slaves as white masters did. In the Lower South, only a tiny portion of successful planters were free women of color, however the majority of this population lived in Louisiana. 
contemporaries. ${ }^{153}$ The economic involvement of free women of color in Louisiana is remarkable for several reasons, the least of which is the fact that they were AfricanAmerican. The prevailing white patriarchal social structure precluded women from the economic sphere to such a degree that to see any woman, whether white or black, as the heads of a successful business or plantation contradicted the accepted structure of the white/black, male/female dichotomy. ${ }^{154}$ It is interesting to note that white men deemed it inappropriate for white women to head a business enterprise yet legally left the way clear for any woman of color who chose to do so.

The most popular means by which free women of color accessed wealth was, however, via long-term engagements with white, propertied males through the practice of plaçage and other, less-defined cohabitation. Interracial relationships occurred not just over the color line, but over economic and social, and while all couples faced intense scrutiny and condemnation, it was the elite quadroons who formed the formal extralegal relationships with wealthy Creole men who bore the brunt of the worst derision and scorn. Neighbors and wives frequently turned their heads if a man exercised his libido with a woman from his own slave pen, yet when the woman was free, few found it possible to overlook the consequences. Ignoring the duration and

${ }^{153}$ Schweninger, "Property-Owning Free African American Women," 22. Schweninger compiled his data from the USMSPC, using various census returns, property records, county court records, and assessment lists. For more detail on computation method, see Schweninger, 37.

${ }^{154}$ It is necessary to note that my discussion of free women of color and their involvement in economic pursuits is strictly limited to the Lower South, particularly port cities that had a large free community of color. The involvement of blacks, free and enslaved, differed from region to region. In the Lower South, free women of color enjoyed a freedom that their Northern counterparts did not. Only in places such as Charleston, New Orleans, and other Louisiana parishes did more than a few women of color own property. 
commitment of many of these relationships and the women's reputations within their own community, outside observers (frequently white family members) maligned the participants and painted them with violent strokes and harsh words, many of which took hold in the historical record and remained unchallenged for generations. Eulalie Mandeville, Delphine Solet, and Fanchon Morres, only to name but a few women, suffered greatly at the hands of relatives, both black and white, who challenged their motives and choice of lifestyle.

Historian John Blassingame's thorough exploration of the occupation of free men of color confirms that there certainly was not a shortage of successful men within their own caste to choose from. The fact that many quadroon women spurned the advances of such men only reinforces the concept that free women of color preferred to take their chances with informal relationships with white men. Why, if there were available, successful, and financial secure free men of color willing, if not vying, to marry quadroon women, would these women opt to form an extralegal relationship offering little security instead of forming a legally sanction union with a homme de couleur?

The concept of interracial marriage as unnatural, explains Peggy Pascoe, stems from the cultural assumptions about the nature of race. It was not until the presidential election of 1864 , that the term "miscegenation" even surfaced. Looking for a term to replace the oft-employed "amalgamation," two politicians crafted the term from the Latin words miscere and genus, the words for mix and race. The term miscegenation, writes Pascoe, sounded more scientific and fitting for the serious 
nature of interracial sex and marriage. ${ }^{155}$ Armed with this new terminology, racial supremacists marched into the new era of post-Civil War America, waving the flag of anti-miscegenation and white supremacy. Thus began the official history of miscegenation law: the history of miscegenation law is, writes Pascoe, "a tragic denial of the rights of personal choice, a sad story of the folly of placing explicit racial categories in the law." ${ }^{156}$ It is this denial of personal choice that has thoroughly saturated historical records concerning interracial relationships in New Orleans. As for the male participants in these "left-handed marriages," Louisiana historian Charles Gayarré noted that "it must be stated that the white man's Liaison [sic] with a quadroon was considered as to much less consequence that a similar affair with a white woman, because in the latter case it might have led to matrimony and other serious results." ${ }^{157}$ Gayarre equated the pull of the Quadroon to that of the fabled Sirens of Ancient Greece. Once involved in a plaçage-type situation, many men succumbed to "the chains which were gradually and imperceptibly forged to hold him captive, became too strong to allow escape from his bondage . .." ${ }^{158}$ In this passage, Gayarré assumes that all men felt trapped in this type of situation, once again stripping away any personal agency or desire. He then hastily adds that the entrapment may be

\footnotetext{
${ }^{155}$ Pascoe, What Comes Naturally, 1.

${ }^{156}$ Pascoe, What Comes Naturally, 5.

${ }^{157}$ Gayarré, "Historical Sketch," 15.

${ }^{158}$ Gayarré, "Historical Sketch," 14.
} 
due, in part, to the fact that "those women behaved with a fidelity to their engagement which afforded no pretext for desertion." 159

It seems that common practice dictated all young, wealthy, white Creole men take a mulatto mistress. Those men that did, did not lose face or prestige in the eyes of respectable, white society. White women reacted to this practice in a variety of ways. Some simply closed their eyes and turned away from the reality of their husbands, sons, and grandson's activities. Others made their spouse's lives uncomfortable and as miserable as possible. White women could legally have a colored woman, either free or enslaved, whipped in public for even minor infractions. More than one white wife attempted to deliver such retribution on her husband's colored mistress. But this tactic could just as easily backfire, with the enraged husband, indignant at the treatment of his mistress, lashing out at his wife. Many men fought duels defending their mistresses, making it clear they would not abide any mistreatment of these women.

Most white wives chose to bear their shame in silence as opposed to lashing out at their husbands in public. They were, however, eager to discuss the indiscretions of their neighbors' husbands. In A Diary from Dixie, Mary Boykin Chessnut noted that, "any lady is ready to tell you who is the father of all the mulatto children in everybody's white household but her own." As for the mulatto children within her own household, she apparently thinks they, "drop[ped] from the clouds." 160 There are

${ }^{159}$ Gayarré, "Historical Sketch," 14-15.

${ }^{160}$ Ben Ames Williams, ed., Mary Boykin Chessnut, A Diary from Dixie (Boston: Houghton Mifflin, 1949), 22. 
incidents where white wives did file for divorce due to their husband's blatant infidelity. Monique Guillory relates, in her dissertation, the story of a Louisiana woman who filed for divorce due to the fact that her husband showed higher regard for his mulatto mistress than for her. The woman further alleged that her husband often took his mistress with him on trips to Paris to visit their son Charles attending school there. His son, boasted the white planter, "would figure fine in the society of Paris."161 The fact that the planter felt such affection for his mulatto son demonstrates the prevalence and de facto acceptance of plaçage relationships.

Eliza Potter, the astute observer of Southern culture and life, recalled an incident between two Northern women, one a free woman of color and the other a white woman, that illustrates how comfortable the free community of color had become with their status. The woman of color was very wealthy and the white woman was not. During the course of their discussion an argument arose over politics. Becoming angry, the white woman started to storm off and exclaimed, "I dont [sic] care, I have the law on my side if you have the money," to which the woman of color retorted, "excuse me madam, I have both." 162 This exchange occurred in the North, yet it is representative of the enmity that existed between those of the lower white classes and the wealthy free population. In turn, there were those of the elite free colored

${ }^{161}$ Guillory, "Some Enchanted Evening," 80, quoted in Helen Tunnicliff Catterall, Judicial Cases Concerning American Slavery and the Negro, vol. III (Washington D.C.: Carnegie Institute of Washington), 491.

${ }^{162}$ Potter, A Hair-Dresser's Experience, 159. 
population who "had as much objection to associating with the free blacks as the whites had to any familiar intercourse with the mixed blooded of the male sex."163

The level of devotion between placeé and placer varied and due to the fact that few, if any, left detailed letters, historians are forced to conjecture using court proceedings, wills, and other remaining legal documents. The fidelity and affection of several men can most easily be discovered through the lens of legal case law. Louisiana jurisprudence decreed that the deceased could will no more than one quarter of his total estate to his natural children or consort. In an attempt to circumvent the law, many of these men enlisted the help of a third party legatee whom they entrusted another portion of their estate. With the estate settled, the legatee was then supposed to transfer his entrusted share of the estate to the deceased's natural children and paramour. Gayarré confirms that it was rare for such legatees to keep the legacy, as they might have; most dutifully transferred the funds intact to the intended. ${ }^{164}$

Unfettered by public opinion or fear of reprisal, many white fathers warmly embraced their mulatto children; according to more than once source, many fathers felt a greater attachment to these children than any they had with a white wife. One such father who openly cherished his natural children was Eugéne Macarty, a well to do merchant of New Orleans, who carried on a relationship with one Eulalie Mandeville for over fifty years. The case of Eulalie Mandeville provides one of the most enlightening case studies of a placeé and her life with a Frenchman, Eugéne

\footnotetext{
${ }^{163}$ Gayarré, "Historical Sketch," 5.

${ }^{164}$ Gayarré, "Historical Sketch," 16.
} 
Macarty. Over the course of fifty years Eulalie built a life with Eugéne Macarty that included several businesses, a sizeable fortune, and five children. Despite the length of their relationship and the evident commitment on behalf of both the parties involved, upon Eugéne's death, his white family forced Eulalie into court to defend her and her children's estate.

Hoping to lay claim to the majority of Eulalie's estate, appraised in excess of $\$ 155,000$, Eugéne's collateral heirs alleged that Eulalie illegally possessed property and money that belonged to Eugéne. ${ }^{165}$ They claimed Eulalie illegally seized \$111,200 in cash as well as an additional $\$ 11,000$, several slaves, lots, and houses within New Orleans. In her defense, Eulalie claimed that the property left to her by Eugéne did not exceed $\$ 12,000$, and that the remainder of the estate, was in fact, her own. Therefore, her council alleged, Eugéne's collateral heirs had no legitimate claim to any additional inheritance. The court records documenting the trial offer a revealing look into the life and activities of Eulalie Mandeville, one that details her birth, childhood, and economic activities as an adult. Eulalie's story is one that should not be taken as representative of all placeés or free women of color involved with white men, yet hers is one of the most detailed and informative that remains.

Born into the Marigny family, one of the oldest and most-respected French Creole families of Louisiana, Eulalie Mandeville grew up within her father's household, as any child would have despite the fact that her mother remained the

${ }^{165}$ Eulalie's estate of $\$ 155,000$ would roughly equate to close to $\$ 4$ million dollars in today's currency and made her the wealthiest free women of color in antebellum America. 
slave. Her white cousin Charles Olivier, testified on her behalf that her father Philip "generally appeared affectionate towards his daughter."166 Her grandmother, by all accounts, doted on Eulalie and saw to her overall education. Raised as tenderly and carefully as any white daughter, Eulalie appears to have maintained a relationship with her white family, continuing to benefit financially from gifts in the form of property and slaves long after leaving the family home. Regardless of the continued connection, the relationship, conjectures historian Virginia Meacham Gould, was strained by race and social conditions. ${ }^{167}$ Fully understanding the options available to a free woman of color, Eulalie plaçed just prior to her twentieth birthday, around 1790 .

By all appearances and court testimony Eulalie and Eugéne remained committed to each other for over fifty years; however, she always retained control of her own finances and business affairs, and lived in a house that she herself owned. Knowing Eugéne since their "youthful days," Eulalie's cousin Charles admitted, "I do not believe that he [Eugéne] had any fortune at the time he began to dwell with [Eulalie]." Yet Eulalie, for her part, already held slaves and real property. Once she resided in New Orleans, she commenced her trade activity. Charles admitted that he did not know for sure whether her trade proved lucrative; however, he was of the

${ }^{166}$ Testimony of Charles Olivier on behalf of Eulalie Mandeville, Macarty et al. v. Mandeville, Supreme Court of Louisiana, New Orleans 3 La. Ann. 239; March 1848 La. UNO archives.

${ }^{167}$ Meacham Gould, "In Full Enjoyment of Their Liberty," 266. 
opinion that she turned a handsome profit confirmed by the several "negresses that pedled [sic] in the city and some time went to the country," under Eulalie's employ. ${ }^{168}$

Duncan Kennedy, a business associate of Eulalie's, also came to her defense attesting to Eulalie's business acumen and solvency. Kennedy was in the dry goods business and engaged in extensive trade with Eulalie, to whom he sold many items. Kennedy attested to the success of the dry goods business in 1811,1812 , and 1813 , years when Eulalie undoubtedly grossed a profit. Eulalie was, commended Kennedy, "remarkably industrious and . . . considered so by all the persons in the place." She was "very industrious and honest." Such was her reputation that Eulalie could apparently "get anything she wanted. ... She could have obtained from 15.000 to 20.000 worth of goods on credit from [Kennedy]. ${ }^{169}$ John Parker, another witness for Eulalie, testified that he had known Eugéne to be a wealthy man involved in discounting notes, but he did not know if the money was actually Eugéne's as he had “ frequently heard that it was with the money of Eulalie Mandeville. [Yet] Macarty had the reputation of being a rich man."170

The testimony of E. Forest claimed that Eugéne told him he had left France without means and arrived in North America practically penniless. Taking into consideration statements by Forest, Olivier, and Kennedy, it would seem that Eugéne

${ }^{168}$ Macarty et al. v Mandeville, Supreme Court of Louisiana, New Orleans, 1847.

${ }^{169}$ Testimony of Duncan Kennedy, Macarty et al. v. Mandeville, Supreme Court of Louisiana, New Orleans, 1847. Orleans 1847.

${ }^{170}$ Testimony of John Parker, Macarty et al. v. Mandeville, Supreme Court of Louisiana, New 
arrived penniless and Eulalie's fortunate formed their basis of their estate. From Eulalie's industriousness and hard work, their holding increased. But according to further testimony by Forest, he did not know Eugéne to be engaged in any business until 1826. ${ }^{171}$ This would lead one to believe Eugéne benefited from Eulalie's endeavors, and not the other way around.

Perhaps one of the more interesting defendants in the Macarty et al. $v$. Mandeville case was that of Eulalie's white brother, B. Marigny. As previously mentioned, Eulalie maintained both an emotional and financial relationship with her white family, but it is still significant that her white sibling recognized this relationship in court and attested to their father's devotion and trust in Eulalie. Marigny confirmed the donation of land located on Bayou Bouf, in addition to 60-80 head of cattle and two lots in Moreau Street (New Orleans). Furthermore, Marigny himself gifted his natural sister lumber from his saw mill with which to build upon the lots. Later, Jean, a second white brother, gave Eulalie funds to purchase another lot of land upon which to build on Hospital Street. Upon Jean's death he left Eulalie a slave named Maturin.

The court rendered judgment June 12, 1847, in favor of Eulalie Mandeville. The case "offered to the moralists a sad instance of the grossest violation of Every social law, of Every lawful tie." Furthermore the jurists admonished one of the plaintiffs for "solicit[ing] money from the defendant, his brother's concubine and to Orleans, 1847.

${ }^{171}$ Testimony of John Parker, Macarty et al. v. Mandeville, Supreme Court of Louisiana, New 
write to her by the all sacred and endearing name of "Sister;" thus wantonly treading on the prejudices of the Country so strong at that period." "It appears," the statement went on, "that all the Said assets, to wit; the money, the slaves and the lots and buildings were at the time of said Eugene Macarty's death, under the name and in the possession of Eulalie Mandeville, the defendant, and that they had been so, for a long time previous to that event. But the heirs contend that the whole was the property of Eugene Macarty and that the sums of one hundred and eleven thousand two hundred and eighty dollars and thirty seven cents, deposited in the Louisiana Bank by Eugene Macarty to the credit of Eulalie Mandeville, and withdrawn by her some time before the death of Eugene Macarty ... was placed ... in the form of a donation inter vivos with the fraudulent purpose of violating the law, and depriving his legitimate heirs of this Estate."172

To this the jurists responded, "The testimony shows ... that when the deceased and the defendant began to live together, they had limited means." Yet together Eugene and Eulalie worked together to amass a sizeable fortune. Eulalie, for her part, "is shown to have been, in her line, a very intelligent, laborious, thrifty, and saving woman." "Deceased and Eulalie had children as aforesaid, and no doubt parental love, the strongest tie on earth suggested to both of them that their own children were perhaps better entitled to inherit the proceeds of their labor, than collateral heirs for whom they felt little or no regard." The court praised the "copious and concordant"

${ }^{172}$ Macarty et al. v. Mandeville, Supreme Court of Louisiana, New Orleans, 1848. 
testimony offered on behalf of Eulalie and pronounced that the testimony offered by the plaintiffs "has not that fore, which can authorise [sic] the Court to determine and decide that plaintiffs have satisfactorily made out their case." ${ }^{173}$

It is important to note that the relationships Eulalie maintained with her white family were primarily with the men. It is pure speculation, but it might be that the women, excluding Eulalie's grandmother, resented Eulalie's existence, particularly her freedom and relationships with the Marigny/Mandeville men. ${ }^{174}$ It seems likely that Eulalie entertained no romantic notions as to her place within society-she knew that legally she was defined as a concubine and that offered very little protection. Unlike many other free women of color she maintained close relationships with her white family. We do not know what relationship, if any, she had with her mother. While it seems likely that Eulalie identified closely with the dominant white culture, she also constructed her own identity within the free Creole community that included entrepreneurship and family. In many ways Eulalie enjoyed more freedom that most white women, yet this freedom rested on a delicate line separating black and white, free and enslaved. As many women of her racial caste did, Eulalie crafted a unique identity that incorporated both her white and African heritage. The balancing of both worlds is indicative of the identities crafted by many free women of color-forced to mold an identity in a cruel slave society dominated by white males, that was neither

${ }^{173}$ Macarty et al. v. Mandeville, Supreme Court of Louisiana, New Orleans, 1848.

174 Testimony of B. Marigny, Macarty et al. v. Mandeville, Supreme Court of Louisiana, New Orleans, 1847. 
black nor white, it was something Creole altogether. Eulalie identified firmly as a member of the free colored community. Those who knew her would identify her as industrious, hardworking, honest, and thrifty, all qualities, writes Gould, that were not usually used to describe southern white women. ${ }^{175}$

Eulalie embraced the benefits of a close association with white society, as did many successful free women of color. Regardless of their industriousness and thrift, there is no denying a direct correlation between elite free women of color and the dominant white class. Identifying as Creoles of color, Gould wrote, associated them with the dominant white Creoles but also served to separate them from the white Americans, as well as from the free black and slaves of the region. ${ }^{176}$ Association with the white class meant benefits and a measure of security, yet also allowed room for a separate identity as a Creole of color. Identifying as Creoles of color meant accepting both halves of one's heritage — the black and the white — while not fully identifying with either.

The story of Amanda America Dickson, while not occurring in Louisiana, does bear importance on this discussion of miscegenation and the relationship between a white father and his mulatto children. The life of Amanda America began in violence; one day her father, David, abducted her mother, Julia, from the Dickson fields and raped her. Amanda, as the bastard child of such a violent coupling, was supposed to disappear into the slave pen and into obscurity; however the opposite occurred-

\footnotetext{
${ }^{175}$ Meacham Gould, "In Full Enjoyment of Their Liberty," 267.

${ }^{176}$ Meacham Gould, "In Full Enjoyment of Their Liberty,” 268.
} 
Amanda grew to be the darling of David and the center of his mother's life. She grew into a privileged young woman who inherited her father's vast fortune and estate, and ultimately married a white man with whom she had several children. Amanda's story is exceptional but enlightening, least of all because of her relationship with her enslaved mother and white family. Her life was made possible largely due to her family's wealth.

As soon as Amanda was weaned, her father took her from her mother and placed Amanda within his own household. It is impossible to know her grandmother's motivations - whether they be out of guilt or genuine affection - but Amanda came to reside with her white family. According to historians Josephine Boyd Bradley and Kent Anderson Leslie, the white Dicksons treated Amanda as they would any child. Legally, Amanda remained a slave. To emancipate her in Georgia in the 1850 s would require sending Amanda out of the state, something her father adamantly refused to do. So until her grandmother's death, Amanda spent the majority of her time reading and learning in the main house. Elizabeth Dickson, her grandson recalled, had "the kindest feelings towards Amanda." ${ }^{, 177}$ Her father, for his part, doted on Amanda and indulged her every whim. The Dickson Family Oral History records that David adored her and even " "bathed [her] in sweet milk to lighten her skin."" 178

${ }^{177}$ Testimony of Augustus E. Eubanks, Dickson Will Case Transcript, Smith v. Dubose, Hancock County Superior Court, Georgia Department of Archives and History, Atlanta, 147 in Josephine Boyd Bradley and Kent Anderson Leslie, "White Pain Pollen: An Elite Biracial Daughter's Quandry," in Sex, Love, Race: Crossing Boundaries in North American History ed. Martha Hodes (New York: New York University Press, 1999), 217. 
David and Elizabeth (her grandmother) socialized Amanda as a member of the white community and not as a member of the free colored population. For all intents and purposes Amanda grew up a member of the elite, white ruling class. Her father made sure she knew how to read, write, and manage business affairs. Her grandmother saw to it that she learned to play the piano, dress the part of a cultured woman, and run a household with efficiency and skill. Amanda's father and grandmother groomed her to be the mistress of a great plantation, a role she rose to with aplomb. At the outbreak of the Civil War, Amanda was twelve. The timing was quite fortuitous for if Amanda had grown up in another time she might not have retained control of her father's fortune and estate. After the war Amanda married a first, white cousin and bore him children - children her father David came to love as much as he did Amanda. David encouraged the children to ride with him over the plantation, ate with them at the same table, and had them call him "Grandpapa." ${ }^{179}$ At one point, David married a white woman who took offense to Amanda and her children. His wife, Clara, attempted to remove Amanda and her children from the plantation and failed due to David's insistence on Amanda's superiority over Clara. Upon his death in 1887, David left his

\footnotetext{
${ }^{178}$ Testimony of Augustus E. Eubanks, Dickson Will Case Transcript, Smith v. Dubose, Hancock County Superior Court, Georgia Department of Archives and History, Atlanta, 147 in Josephine Boyd Bradley and Kent Anderson Leslie, "White Pain Pollen: An Elite Biracial Daughter's Quandry," in Sex, Love, Race: Crossing Boundaries in North American History ed. Martha Hodes (New York: New York University Press, 1999), 217.

${ }^{179}$ Testimony of Joe Brookens, Dickson Will Case Transcript, Smith v. Dubose, Hancock County Superior Court, Georgia Department of Archives and History, Atlanta, 147 in Josephine Boyd Bradley and Kent Anderson Leslie, "White Pain Pollen: An Elite Biracial Daughter's Quandry," in Sex, Love, Race: Crossing Boundaries in North American History ed. Martha Hodes (New York: New York University Press, 1999), 224.
} 
entire estate to his daughter and grandsons, making them the largest property owners in Hancock County, Georgia, and possibly the richest mulattos in the state. ${ }^{180}$ Furthermore, and curiously, David left the administration of his estate to the "'sound judgment and unlimited discretion,"” of Amanda “"without interference from any quarter," more specifically "'any husband which she may have.", 181

David Dickson's affection for his daughter is representative of the love many white fathers' held for their "natural" children. In Louisiana, strict laws regulated the donation of money from white fathers to colored children; however, it appears that such laws did not prevail in Georgia. Many fathers attempted to find ways around the inheritance and donation laws of Louisiana. Many cases support the attempts and failures of many fathers to secure the futures of their natural, mulatto children. The outcome of such cases are important in and of themselves; however, what is most important is the love and concern such men held for children that society believed were aberrant and deserving of nothing.

Emma, Lavinia, and Octavia Miller were another group of women who firmly identified as free women of color within the Creole community. The Millers, of New Orleans, corresponded heavily with their Aunt Ann Johnson, of Natchez, Louisiana. The contents of these letters focus on their husbands and children, daily concerns such

\footnotetext{
${ }^{180}$ Josephine Boyd Bradley and Kent Anderson Leslie, "White Pain Pollen: An Elite Biracial Daughter's Quandry," in Sex, Love, Race: Crossing Boundaries in North American History ed. Martha Hodes (New York: New York University Press, 1999), 227.

${ }^{181}$ David Dickson's Will, March 2, 1885, Probate Court Records, Drawer D, Hancock County Courthouse, Sparta, Ga., in Josephine Boyd Bradley and Kent Anderson Leslie, "White Pain Pollen: An Elite Biracial Daughter's Quandry," in Sex, Love, Race: Crossing Boundaries in North American History ed. Martha Hodes (New York: New York University Press, 1999), 227.
} 
as weather and sickness, revealing the importance of family and community to these women of color. In her dissertation and subsequent book, historian Virginia Meacham Gould outlined the lives of the Millers and Ann Johnson. Catholicism, explained Gould, reinforced their roles as wives and mothers. Catholic doctrine emphasized the importance of family and the submission of wives to their husbands-both of which, Gould argues, the Miller-Johnson women accepted, albeit in a different manner than their white counterparts. ${ }^{182}$

Accepting the social conditions, yet at the same time refusing to be victims of the abusive slaveholding society in which they lived, the Miller-Johnson women went about their lives constructing meaningful relationships within their own community. The young women, wrote Gould, often visited their aunt bringing her goods and items from New Orleans not available in Natchez or vice versa. The Millers sent their Aunt fabric, lace, shoes, gloves, coffee, and soap. In return Ann sent vegetables from her garden and fruit from her orchards. ${ }^{183}$ The Miller-Johnson women fulfilled their roles as women but also as slaveholders. Ann Johnson owned several slaves who worked her farm and also a few that worked within her home. The fact that the older generations of the Miller-Johnson family had been slaves did not alter the economic practicality of owning and benefiting from slave labor. Ironically, Gould noted, while

\footnotetext{
${ }^{182}$ Meacham Gould, "In Full Enjoyment of Their Liberty," 14.

${ }^{183}$ Meacham Gould, "In Full Enjoyment of Their Liberty," 18.
} 
Ann Johnson owned slaves, the women resented the open racism of their white neighbors. ${ }^{184}$

There were, on occasion, free women of color who preferred to distance themselves from the white community and looked down upon those women who chose to consort, either legally via passing or illegally via concubinage, with white men. Lavinia Miller wrote to her aunt, Ann Johnson, about Manda, a free woman of color who resided in her community. "Manda is married to a white man last saturday night. Madame Amie was not at the wedding nor her sister Kittey. None but the family - an [sic] not all of them. Her mother says that the man has been courting her eight years and she told me that he was going to bay of St. Louis to marry because they could not get lawful married here. That was fool to me. But madame [sic] Amie told me that they did not go. That they had the French Priest to make the serremony [sic] at the house without licens[sic]. Now what you call that.[sic]" ${ }^{\text {185 }}$ As a member of New Orleans's elite free class Lavinia Miller reveals that interracial marriages were beneath respectable women of color. Miller, herself, married a prominent free man of color and lived a comfortable life.

${ }^{184}$ Meacham Gould, "In full enjoyment of their liberty," 19. In one letter Emma questioned why her Aunt had comforted a white man within her community when, if the situation had been reversed, the man would not have comforted Ann. Instead of socializing with the whites in their community, it seems that the Miller women separated themselves from the whites in their community and preferred to socialize within their own community.

${ }^{185}$ Letter from Lavinia Miller to Ann Johnson, December 2, 1848, in Virginia Meacham Gould, Chained to the Rock of Adversity: To Be Free, Black, \& Female in the Old South (Athens, GA: The University of Georgia Press, 1998), 7. 
Many free men of color resented the free women of color who chose to engage in sexual relationships with white men, as well as those who attempted to pass into white society. These feelings are revealed in a song about a young woman nicknamed Toucoutou, who had been passing as white. An angry neighbor called her a "Negro," compelling Toucoutou to press her case in court, something that many people of color did to prove their "whiteness." 186

Joseph Beaumont, a free man of color, commemorated his resentment and the story of Toucoutou in verse:

${ }^{186}$ Shirley Thompson, “'Ah, Toucoutou, ye conin vous': History and Memory in Creole New Orleans." American Quarterly 53 (June 2001): 232-266. The story of Toucoutou is repeated in Thompson, however the actual transcript from the court case has been lost, destroyed, or taken; however, the story of Toucoutou, and her notoriety, has been passed from historian to historian through several generations. 


\section{Toucoutou}

Si vous té gagné vous procé

Oh, négue cé maléré

Mové dolo qui dans focé

Cé pas pon méprisé

Refrain:

Ah Toucoutou, ye conin vous

Vous cé tin Morico

Na pa sacon qui tacé blanc

Pou blanchi vous lapo

$\mathrm{Au}$ Théâtre même quand va prend loge

Comme tout blanc comme y fot

Ye va fé vous prend Jacdeloge

Na pas pacé tantôt

Refrain

Quand blanc loyés va donin bal

Vous pli capab aller

Comment va fé, vayante diabol

Vous qui laimez danser

Refrain

Mo pré fini mo ti chanson

Pasqui manri dormi;

Mé mo pensé que la leson

Longtemps li va servi

Refrain

\section{Toucoutou}

If you win your lawsuit, Indeed, O Negress, this is bad;

Bad for those who force it

And the harm can not be disregarded.

Refrain:

Ah Toucoutou, we know you!

You are a little Mooress

Who does not know you?

No soap will make you white

At the theater, if you go there,

Like all white people should,

They will treat you like a Jacdeloge,

Who did not pass so well as White, did he?

Refrain

When these White lawyers give a dance,

Will you be able to go?

Will you, $O$ beautiful devil,

You who love to dance so!

Refrain

I have finished my little song

Because I want to sleep

But I think the lesson will serve,

For a long time to keep you meek.

Refrain

This song reveals only one man's perspective but is representative of a large portion of the free colored community, according to the historian and free Creole of color, Rodolphe Lucien Desdunes. ${ }^{187}$ Beaumont clearly did not approve of gens de

${ }^{187}$ Rodolphe Lucien Desdunes Our People and Our History, trans. Sister Dorothea Olga McCants (Baton Rouge: Louisiana State University Press, 1973), 63-64. 
couleur libre who attempted to pass as white. A quadroon himself, Beaumont condemned the young Toucoutou for acting so foolish as to try to prove her whiteness in a court of law; ultimately he and others who disapproved of passing were ultimately vindicated by the court's revelation of Toucoutou's African ancestry. The tale of Toucoutou, Beaumont hoped, would serve as a warning to other light-skinned gens de couleur libre who hoped to pass into the white community and reap all the benefits of belonging to the ruling class. Those that tried to prove their whiteness and failed lost not only the privileges they enjoyed, but also the respect of both the free and white communities. The phenomena of passing, wrote Desdunes, created a division within the free community. "When the Negro tries to be white, Society will finish him," Beaumont advised in another poem, voicing his belief in solidarity. ${ }^{188}$ Historical records show that men and women from a wide spectrum of ethnicities and communities participated in passing in an effort to thrive and prosper in racist societies. Yet Beaumont chastised Toucoutou for trying to pass as white and sings that she will now be treated "like a Jacdeloge, Who did not pass so well as White, did he?" Just as free people of color sought to separate themselves from the enslaved population, free men of color hoped to distance themselves from the white population as well.

One free man of color who clearly did not approve of libre women cohabitating with white men took his daughter to court over the accusation of slander and a judgment of five dollars. Delphine Solet left her father's home to live in concubinage with a white man. Upon her departure, her father accused her of being "the most base and infamous person that ever lived." 189 It does not take any stretch of the imagination to understand how Jean Baptiste Solet felt about his daughter's

188 Desdunes, 61-63.

${ }^{189}$ Delphine Solet v. Jean Baptise Solet 1 Rob. 339, (February 1842), Earl K. Long Library, University of New Orleans, New Orleans. LA. 
decision. After his daughter sued him for slander and won a judgment of five dollars, Jean Baptiste appealed the court decision. One can only conclude that he felt so strongly about his daughter's choice of lifestyle that he felt it necessary to defend the slander verdict in light of Delphine's five-dollar victory. Jean Baptiste appealed to the Louisiana Supreme Court and ultimately the judgment of the Lower Court was overturned. The Supreme Court judged that Jean Baptiste had spoken the words in "a moment of irritation," and that it appeared he "was under the influence of a sense of duty rather than prompted by malice to injure her. If during the excitement under which he was, he used an expression which, if applied to any other person, than a guilty daughter, might be imputed to a malicious intention. ${ }^{, 190}$ He was, however, speaking from a position of concern and responsibility, therefore he could not be convicted of slander, only guilty of wanting his daughter to marry a man of her own class and standing.

Despite the fact that many free men of color resented the intrusion of white males into their community, it is undeniable that they benefited from it was well. As previously discussed, much of the initial wealth fed into the free community of color came from white men and served as the basis for the creation of more wealth. No case study better illustrates this process than the story of Coincoin and the dynasty she founded. Born in 1742, Coincoin served as a house slave for many years when she met a newly immigrated Claude Thomas Pierre Metoyer. Taking a liking to Coincoin, Metoyer persuaded her owners to lease her to him in exchange for her room and

${ }^{190}$ Delphine Solet v. Jean Baptise Solet 1 Rob. 339, (February 1842), Earl K. Long Library, University of New Orleans, New Orleans. 
board. In the following twenty years, Coincoin and Metoyer gave birth to ten children. Coincoin was, nevertheless, legally still a slave and her children followed her into the institution. Despite the fact that Coincoin and Metoyer had lived openly as man and wife for twenty years, their children legally belonged to the de Soto's, Coincoin's legal owners. Further complicating the matter, a local priest who baptized six of Metoyer's children with Coincoin felt he could no longer ignore Coincoin and Metoyer's open concubinage. This Father Quintanilla advised the couple to marry, but this option proved to be impractical as anyone engaged in an interracial marriage, by law, was forced from the colony. Next the priest suggested that Coincoin leave Metoyer's home and set up her household elsewhere. When Coincoin and Metoyer refused all his suggestions, Father Quintanilla proceeded to file charges of open concubinage against the two and demanded that Coincoin's mistress, Mme. de Soto, control her slave. Incensed over the accusations Mme. de Soto vigorously defended herself, Coincoin, and Metoyer, threatening to take her case to as high a church authority as necessary to prevent Father Quintanilla's meddling. ${ }^{191}$

In 1776, Metoyer drew together funds to purchase the oldest four of his and Coincoin's children, and in 1778, he proceeded to purchase Coincoin and their youngest child. Under the Code Noir, however, any master who fathered children with his slave could be forced to forfeit the slave and child. Therefore, in 1778, Metoyer drew up a private document that liberated Coincoin and her youngest child. Coincoin

${ }^{191}$ Gary Mills, "Coincoin: An Eighteenth-Century "Liberated" Woman," The Journal of Southern History, 42:2 (May 1976), 207-210. 
had her freedom and three more children. Coincoin remained with Metoyer for eight more years until they, by all appearances, agreed to end their relationship. Metoyer granted her a tract of eighty arpents from his main plantation and agreed to pay her a lifetime stipend of 120 piasters a year.

From Metoyer's meager gift grew Coincoin's legacy, family, and wealth.

Coincoin decided that she and her children would grow tobacco, a crop that demanded intense labor and close attention. By 1792, Coincoin grew enough tobacco that she required an entire barge to carry her crop to New Orleans. To supplement her income, it is said that Coincoin trapped bears to turn into grease for sale in European markets. ${ }^{192}$ Through her sharp business acumen and thriftiness, Coincoin ultimately succeeded in purchasing all her children and grandchildren that Metoyer could not liberate. After securing her children's freedom, Coincoin turned to purchasing more land and slaves. By 1816, Coincoin owned at least twelve slaves and church registers record at least four others who lived on her plantation. ${ }^{193}$ Upon her passing, Coincoin left a considerable fortune to her children and a solid base upon which they built their lives as gens de couleur libre, and as plantation and slave owners.

The evidence left behind by women such as Coincoin, Eulalie Mandeville, and the Millers demonstrated beyond question the role of family and community in the formation of identity for Louisiana's free women of color. The home and children formed the foundation of everyday routine and priorities. These women did not lead

\footnotetext{
${ }^{192}$ Mills, "Coincoin," 214.

${ }^{193}$ Mills, "Coincoin," 217.
} 
lives in the pursuit of fancy clothing and pretty trinkets-they lived to better themselves and their children through business ventures and advantageous alliances with the dominant class, as well as within their own community. In the process, they created a community of highly intelligent, industrious individuals that happened to be centered upon, to a large degree, single women. 


\section{Conclusion}

\section{"and they captivated all who were present."}

Beauty-it is something coveted by men and women alike. By all accounts a desirable characteristic, the Quadroons of New Orleans possessed such beauty to the point that they drove men to duels, suicide, and financial ruin. Finely dressed in the latest fashion, displaying glittering jewels purchased by their lovers, they flit across the pages of history. Fair enough to pass as white yet forever linked to the enslaved population, the Quadroons of New Orleans garnered more contemporary attention than possibly any other group of women in the Gulf Atlantic. No trip to New Orleans was complete without a visit to the fabled Quadroon balls, regardless of one's moral or social stance on miscegenation. Even the most xenophobic tourists begrudgingly acknowledged the curious allure of the exotic beauties. In light of the abundant testimony concerning their physical attributes, it is easy to understand how beauty became their primary bequest to history. Beauty, however, is a passive virtue, a gift of nature. Beauty, as it is said, is only skin-deep and notes nothing of accomplishment or action. Distilling the image of the Quadroons down to this one word belies their real nature and trivializes their contributions to the Creole and American culture.

New Orleans' locals love to tell stories, particularly about their colorful past and characters. The Quadroons logically are a favorite topic of choice. Historically, the Quadroons of New Orleans have been equated at best to the famed courtesans of Europe and at worst as greedy whores prostituting themselves to the highest bidder in a practice colloquially called plaçage. To some, the balls only served to facilitate the 
display of goods and the ensuing negotiations. Others argue they were just a small step away from the auction block—a socially indoctrinated sex trade—where young girls of similar skin color could be bought for exorbitant prices. The majority of firsthand accounts left to historians come from outsiders who did not understand the spectacle of the balls any more than they did the Creole's love of French culture amidst a city rapidly becoming Americanized. Local observations vacillate between roundly condemning all parties involved and glorifying the unique exhibition of beauty and sexuality. The abolitionists co-opted the Quadroon's body for their own aims, portraying her as a wretched creature, tragically outcast from both black and white society. In the mid-twentieth century, new attention to black history naturally called into question the body of the Quadroon. Being a non-white woman in Antebellum Louisiana, nonetheless, she ironically became a part of a group that during her lifetime she actively sought to distance herself from. The women themselves, unfortunately, remained silent on the subject. It is time, however, to look for their voices elsewhere.

Miscegenation is nothing new in North America or in colonial societies, but the way in which it manifested itself in Southeastern Louisiana is fairly unique, as were the ways in which the colonial authorities dealt with it. In the Northern Anglo states, children born of an African mother and white father typically followed their mothers into the slave pen and lived their lives in relative anonymity. Emancipation was not encouraged nor was it socially acceptable to liberate concubines. No slave code could be considered kind or lenient. Comparatively speaking, however, the Black Code employed by the French and Spanish proved more amenable to liberation of the 
enslaved. The Spanish legal code created room for a class of free people and French cultural attitudes toward civility allowed for more permeable, fluid boundaries between black and white, free and enslaved.

Certainly an account of plaçage must be placed within the history of the exploitation of African-American women by white males. Interracial sexual encounters often were predominantly violent and forced, and rarely consensual. As women and as people of color, quadroon women faced discrimination on two fronts. It is, therefore, understandable how historians failed to differentiate the experiences of free women of color from those of other black women. For a group of free persons of mixed ethnicity who "had been taught from childhood to abhor anything black," it seems methodologically unsound to equate their experiences with those of enslaved women. ${ }^{194}$

A shared heritage of African or Caribbean ancestry and gender are the only two aspects free women of color and black women had in common. These two qualities did little to inspire a sense of solidarity between the two groups. Born free, the Quadroons of Louisiana identified as such, and never knew life as anything else. Regardless of the fact that at least one of their ancestors knew the lash and yolk of slavery, to identify as a free Creole of color meant at least one full generation, typically two or more, away from slavery. The influence of knowing oneself as free in a slave society should not be underestimated and cannot be overemphasized. In no

\footnotetext{
${ }^{194}$ Marcus Christian Collection, Box 14 Literary and historical Manuscripts, Historical Genealogy, "The Creoles of Louisiana, White Men and Negro Women." Folder One. Special Collections, Earl K. Long Library, University of New Orleans, New Orleans.
} 
way do I mean to imply that freedom translated to equality in Antebellum America, yet in Gulf port cities such as New Orleans it meant unprecedented liberties and social advantages not enjoyed by counterparts in Northern cities.

One of those extraordinary liberties was the Quadroon ball. A term passed down throughout history to denote dances frequented exclusively by white men and free women of color, these events developed out of the French love of dance and sociability. In a city occupied by Frenchmen, Spaniards, and Americans, communication often proved difficult--dancing did not require talking. In a society divided along the color line, clearly non-whites could not attend white balls. As a result, the free Creole population began throwing dances of their own, reinforcing their identities as a distinct community. The class and glamour of the colored dances eventually drew a large white audience and lacking legal support, the Creoles of color could not bar whites from their affairs. Eventually the nature of the dances changed as their quality and respectability varied, as did that of the ladies who attended. Not every young woman who attended these balls did so with the goal of securing a lover. Many simply went to socialize, gossip, and dance.

Using the blessings bestowed by nature, many women found that the surest path to social mobility and security lie in close relations to the white community. Logic dictates that close association with the ruling faction results in certain benefits. Marriage has always been an instrument employed by men to improve family fortunes or to form beneficial social connections. Why should the aims of mothers be any different? Seeing more opportunity in forming extralegal, left-handed marriages, many 
Quadroon matrons (and white fathers), encouraged their young daughters to consider forming a plaçage relationship. Dances, akin to debutant balls, served as one way to facilitate such connections as much as any cotillion thrown by Anglo-Saxon matrons.

One young woman who found her future in a plaçage relationship was Eulalie Mandeville. The case of Eulalie Mandeville should not be taken as illustrative of the majority of all plaçage relationships. Nevertheless, the duration and commitment of her relationship with Macarty demonstrates the seriousness with which many women approached plaçage relationships. Furthermore, her ability to successfully maneuver the legal system is indicative of the powers possessed by all free women of color. Eulalie's father, a wealthy white Creole, placed Eulalie with Eugene Macarty, a man he deemed suitable for his natural daughter. The affection testified to by not only Eulalie's friends, but also her white relations, speaks to the complex nature of family, identity, and socially accepted norms. Using the courts to assert her legal rights, Eulalie effectively defended her estate and the future of her children. Eulalie's fortunes may have been directly tied to the white community, considering that her father and brother had both gifted her land and money. Yet through her own thrift and industry, she developed a lucrative business and amassed a respectable fortune of her own. Should the fact that she chose to live in "open and notorious concubinage" detract from her contribution to her family and community?

Proper Antebellum ladies relied on fathers and husbands to sustain their household and provide for their financial needs. Free women of color could not rely on consistent male support, partly due to the lack of suitable male partners since many 
young men of color opted to leave Louisiana to seek their fortunes elsewhere. As the legal history of Louisiana indicates, light, but not white, free women of color had access to resources unavailable to liberated black women and wielded more personal freedom that white women.

The relative freedom of antebellum free women of color can be seen in their role as heads of households. In 1791, out of a total 196 households comprised of free people of color, women headed 148 of them. By 1820, women headed 411 of the 559 free households. ${ }^{195}$ As active participants in the economic and cultural life of the city, free women of color effected decisions most women left up to men. Thrust into the position as heads of household and functioning as legally single women, the success and failures of the family, and by extension, the community, rested on the shoulders of these women. Excluded from the white community and shunning the black, the women who inhabited the area in between drew tightly together, creating their own community complete with social clubs, schools, and institutions. The free Creoles of color developed their own society based on a shared identity, language, religion, customs, and heritage with a large role for single women, a practice outside observers could rarely fathom. During the late-antebellum years this community reached a high degree of culture, education, and prosperity all directly attributed to miscegenation and plaçage relationships. Despite the controversial origins of free Creoles of color, their influence on Louisiana culture is remarkable.

${ }^{195}$ Meacham Gould, "In Full Enjoyment of Their Liberty," 319. 
By their very nature exploitive, plaçage relationships must have offered more security that not. Yet the experiences of the women who engaged in such relationships must not be equated to the female house slave kept by her master to sate the libido his white wife denied. A logical outgrowth of French traditions of dance and culture, the proprietary balls should not be considered blatant showrooms where mothers eagerly auctioned off their daughters' virtue. The contracting of such financial agreements should not be equated to prostitution, but to a dowry.

Young women in antebellum America were raised with the expectation that they would marry, bear children, and faithfully serve their husbands. The model of white domesticity and womanhood stipulated that women be chaste, demure, and obedient to their fathers, husbands, and brothers. Marriage, wrote historian Nancy Cott, meant turning two people into one person-the husband. The husband absorbed the identity of his wife, and according to the doctrine of coverture, the wife could not pursue lawsuits, contracts, or own assets without her husband's assistance or cooperation. She lost all responsibility for herself-her husband becoming both the legal and political representative of his wife. ${ }^{196}$ Marriage, particularly in Antebellum America, meant a loss of identity and self-determination.

The expectations of young Creoles women of color were much the same as they were in the white bourgeois community yet the harsh reality of the oppressive racial climate impacted the options available to them. Since it was illegal for women of color to contract a marriage with either an enslaved or white man, the options for

\footnotetext{
${ }^{196}$ Nancy F. Cott, Public Vows A History of Marriage and the Nation (Cambridge: Harvard University Press, 2000), 11-12.
} 
acceptable mates could be severely limited. Legally they could only marry men of their own caste. Contracting a legal marriage meant certain submission, the possible loss of assets gifted from fathers, as well as an overall loss of independence and selfdetermination. Marriage to a free man of color also meant that any children born of the union would certainly be darker in complexion. In a culture where skin color served as a form of currency, freedom balanced delicately on appearance.

White gender and social conventions factored only minimally into the lives of New Orleans free women of color, with the accepted social norms of their unique society taking precedence. Neither white nor black, free women of color were forced to create a community somewhere in between, adapting their lives in order to straddle the divide between white and black, free and enslaved. Identifying more closely with the African model of womanhood than the white, they accepted the model of selfreliance and independence. Regardless that the white matrons "looked down with lofty contempt ... at beings whom they considered unworthy of notice" the Quadroons gloried in their beauty and used what resources they had available to thrive under highly oppressive circumstances. ${ }^{197}$ Understanding the innate differences in world view and cultures, and realizing that with independent treatment, the picture that emerges is not one of passive, victimized beauty, but one of fierce determination and strength-one of agency, not submissiveness.

${ }^{197}$ Gayarré, "Historical Sketch," 12. 


\section{Sources Consulted}

\section{Archives and Collections:}

Marcus Christian Collection, Earl K. Long Library, University of New Orleans, New Orleans, Louisiana.

Charles Gayarré Collection, Hill Memorial Library, Louisiana State University, Baton Rouge, Louisiana

Historic New Orleans Collection and Williams Research Center, New Orleans, Louisiana

\section{Newspapers:}

New Orleans Gazette

New Orleans L'Abeille,

New Orleans Moniteur

New Orleans Times Picayune

Niles Weekly Register, New York

\section{Primary Sources:}

Cable, George Washington. Strange True Stories of Louisiana. New York: Charles Scribner's Sons, 1901. 1901. . The Creoles of Louisiana. New York: Charles Scribner's Sons,

Delphine Solet v. Jean Baptise Solet 1 Rob. 339, (February 1842).

de Tocqueville, Alexis. Journey to America. Translated by George Lawrence. Westport, Conn.: Greenwood, 1971.

Documents of the Cabildo, accessed December 18, 2008, www.nutrias.org/exhibits/purchase/page15tr.htm

Fanchon Morres v John Compton, 12 Rob. 76. Supreme Court of Louisiana, Western District, Alexandria, 1845.

Gayarré, Charles. "Historical Sketch-The Quadroons of Louisiana," English Version, Special Collections, Hill Memorial Library, Louisiana State University, Baton Rouge. 


\section{Sources Consulted}

\section{Archives and Collections:}

Marcus Christian Collection, Earl K. Long Library, University of New Orleans, New Orleans, Louisiana.

Charles Gayarré Collection, Hill Memorial Library, Louisiana State University, Baton Rouge, Louisiana

Historic New Orleans Collection and Williams Research Center, New Orleans, Louisiana

\section{Newspapers:}

New Orleans Gazette

New Orleans L'Abeille,

New Orleans Moniteur

New Orleans Times Picayune

Niles Weekly Register, New York

\section{Primary Sources:}

Cable, George Washington. Strange True Stories of Louisiana. New York: Charles Scribner's Sons, 1901. The Creoles of Louisiana. New York: Charles Scribner's Sons, 1901.

Delphine Solet v. Jean Baptise Solet 1 Rob. 339, (February 1842).

de Tocqueville, Alexis. Journey to America. Translated by George Lawrence. Westport, Conn.: Greenwood, 1971.

Documents of the Cabildo, accessed December 18, 2008, www.nutrias.org/exhibits/purchase/page15tr.htm

Fanchon Morres v John Compton, 12 Rob. 76. Supreme Court of Louisiana, Western District, Alexandria, 1845.

Gayarré, Charles. "Historical Sketch-The Quadroons of Louisiana," English Version, Special Collections, Hill Memorial Library, Louisiana State University, Baton Rouge. 
. History of Louisiana: The Spanish Domination vol. III. $3^{\text {rd }}$ edition. New Orleans: Armand Hawkins, 1885.

Jeronimus, William, ed. Travels by His Highness Duke Bernhard of Saxe-WeimarEisenach Through North America in the Years of 1825 and 1826. University Press of America, Inc.: New York, 2001.

King, Grace. New Orleans, the Place and the People. New York: Macmillan \& Co., 1895.

Latrobe, Benjamin Henry. The Journal of Latrobe: Being the Notes and Sketches of an Architect, Naturalist, and Traveler in the United States from 1796-1820. New York: D. Appleton and Company, 1905.

Latrobe, John H.B. Southern Travels. Samuel Wilson, Jr. ed. New Orleans: The Historic New Orleans Collection, 1896.

le Page du Pratz, Antoine. The History of Louisiana, or of the Western Parts of Virginia and Carolina: Containing a Description of the Countries that Lie on Both Sides of the River Mississippi: with an Account of the Settlements, Inhabitants, Soil, Climate, and Products. London: T. Becket, 1774.

Lislet, L. Moreau and Henry Carleton, trans. The Laws of Las Siete Partidas, Which are Still in Force in the State of Louisiana. Vol. 1. New Orleans: James M'Karaher, 1820.

Lyell, Sir Charles. A Second Visit to the United States of North America, vol I. New York: Harper Brothers, 1849. . A Second Visit to the United States of North America. Vol. II. New York: Harper \& Brothers, 1849.

Macarty et al v. Mandeville Supreme Court of Louisiana, New Orleans 3 La. Ann. 239; 1848 La. Lexis 128.

Macarty et al. v Mandeville, Supreme Court of Louisiana, New Orleans, 1847.

Martineau, Harriet. Society in America. London: Saunders and Otley, 1837. 
McCants, Sister Dorothea Olga, trans. Our People and Our History. Baton Rouge: Louisiana State University Press, 1973. Originally published in Rodolphe Lucien Desdunes, Nos Hommes et Notre Histoire : Notices Biographiques Accompagnées de Reflexions et de Souvenirs Personnels, Hommage à la Population Créole, en Souvenir des Grands Hommes qu'elle a Produits et des Bonnes Choses qu'elle a Accomplies, (Montréal : Arbour \& Dupont, 1911).

Olmstead, Frederick Law. Journey in the Seaboard Slave States with Remarks on Their Economy. New York: Dix and Edwards, 1856.

Potter, Eliza. A Hair-Dresser's Experience in High Life. Cincinnati: Privately published, 1859.

\section{Secondary Sources:}

Asbury, Herbert. The French Quarter: An Informal History of the New Orleans Underworld. New York: Thunder's Mouth Press, 1936.

Aubert, Guillaume. "The Blood of France": Race and Purity of Blood in the French Atlantic World." The William and Mary Quarterly 61:3 (July 2004): 439-478.

Baptist, Edward E. “'Cuffy,' 'Fancy Maids,' and 'One-Eyed Men': Rape, Commodification, and the Domestic Slave Trade in the United States." The American Historical Review 106:5 (Dec. 2001): 1619-1650.

Berlin, Ira. Slaves Without Masters The Free Negro in the Antebellum South. New York: New York University Press, 1978.

Blassingame, John. Black New Orleans, 1860-1880. Chicago: University of Chicago Press, 1973.

Blumenthal, Walter Hart. Brides from Bridewell: Female Felons Sent to Colonial America. Rutland, VT: Charles E. Tuttle Co., Inc., 1962.

Bradley, Josephine Boyd and Kent Anderson Leslie."White Pain Pollen: An Elite Biracial Daughter's Quandry." In Sex, Love, Race: Crossing Boundaries in North American History, ed. Martha Hodes, 213-236. New York: New York University Press, 1999.

Brasseaux, Carl. "The Moral Climate of French Colonial Louisiana, 1699-1763." Louisiana History: The Journal of the Louisiana Historical Society 27:1 (Winter 1986): 27-41. 
ed. A Refuge for All Ages: Immigration in Louisiana History, vol. 10 of the Louisiana Purchase Bicentennial Series in Louisiana History: Lafayette: University of Southwestern Louisiana Press, 1996.

and Glenn R. Conrad, eds. The Road to Louisiana: The SaintDomingue Refugees, 1792-1809. Lafayette: Center for Louisiana Studies, University of Southwestern Louisiana, 1992.

Chessnut, Mary Boykin. A Diary from Dixie. Boston: Houghton Mifflin, 1949.

Cocuzza, Dominique. "The Dress of Free Women of Color in New Orleans, 1780 1840," Dress 27 2000: 78-87.

Conrad, Glen R., ed. The French Experience in Louisiana. Lafayette: University of Southwestern Louisiana, 1995.

Cott, Nancy F. Public Vows A History of Marriage and the Nation. Cambridge: Harvard University Press, 2000.

Crete, Lillian. Daily Life in Louisiana, 1815-1830. Trans. Patrick Gregory. Baton Rouge: Louisiana State University Press, 1981.

Dawdy, Shannon Lee. Building the Devil's Empire: French Colonial New Orleans. Chicago: University of Chicago Press, 2008.

Dessens, Nathalie. From Saint-Domingue to New Orleans: Migration and Influences. Gainesville: University Press of Florida, 2007.

Domínguez, Virginia. White by Definition: Social Classification in Creole Louisiana New Brunswick, N.J.: Rutgers University Press, 1986.

Dunbar-Nelson, Alice. "People of Color in Louisiana, Part II," Journal of Negro History 2:1 (Jan. 1917): 51-78.

Early, Eleanor. New Orleans Holiday. New York: Rinehart and Company Inc., 1947.

Everett, Donald. "Free Persons of Color in Colonial Louisiana." Louisiana History 7 (1966): 21-50.

Fiehrer, Thomas. "Saint-Domingue/Haiti: Louisiana's Caribbean Connection." Louisiana History 30:3 (Fall,1989): 419-437. 
Foner, Laura. "The Free People of Color in Louisiana and St. Domingue: A Comparative Portrait of Two Three-Caste Societies." Journal of Social History 3 (Summer 1970): 406-430.

Garraway, Dorris. The Libertine Colony: Creolization in the Early French Caribbean. Durham: Duke University Press, 2005.

Gehman, Mary. "Visible Means of Support: Businesses, Professions, and Trades of Free People of Color." In Creole: the History and Legacy of Louisiana's Free People of Color, ed. Sybil Kein, 208-222. Baton Rouge: Louisiana State University Press, 2000.

Genovese, Eugene. Roll, Jordan, Roll: The World the Slaves Made. New York: Pantheon Books, 1974.

Gould, Virginia Meacham. Chained to the Rock of Adversity: To Be Free, Black, \& Female in the Old South. Athens, GA: The University of Georgia Press, 1998.

. "Henriette Delille, Free Women of Color, and Catholicism in Antebellum New Orleans, 1727-1852. In Beyond Bondage: Free Women of Color in the Americas, eds. David Barry Gaspar and Darlene Clark Hine, 271285. Urbana: University of Illinois Press, 2004.

. "In Full Enjoyment of Their Liberty: The Free Women of Color of the Gulf Ports of New Orleans, Mobile, and Pensacola, 1769-1800." Ph.D.diss., Emory University, 1991.

Griebel, Helen Bradley, "The African American Woman's Headwrap: Unwinding the Symbols," accessed August 21, 2008, http://char.txa.cornell.edu/Griebel.htm

Guillory, Monique. "Some Enchanted Evening on the Auction Block: The Cultural Legacy of the New Orleans Quadroon Balls." Ph.D. diss., New York University, 1999.

Hall, Gwendolyn Midlo. "African Women in French and Spanish Louisiana Origins, Roles, Family, Work, Treatment." In The Devil's Lane Sex and Race in The Early South. Eds. Catherine Clinton and Michelle Gillespie, 247-262. Oxford: Oxford University Press, 1997.

."The Franco-African Peoples of Haiti and Louisiana," Southern Quarterly 44:3 (Spring 2007): 10-17. 
. Africans in Colonial Louisiana: The Development of Afro-Creole Culture in the Eighteenth Century. Baton Rouge: Louisiana State University Press, 1992.

Ingersoll, Thomas N. Mammon and Manon in Early New Orleans: The First Slave Society in the Deep South, 1718-1819. Knoxville: University of Tennessee Press, 1999.

Johnson, Jerah. "Colonial New Orleans: A Fragment of the Eighteenth-Century French Ethos." In Creole New Orleans: Race and Americanization. Eds. Arnold R. Hirsch and Joseph Logsdon, 12-57. Baton Rouge: Louisiana State University Press, 1992.

. Congo Square in New Orleans. New Orleans: Louisiana Landmarks Society, 1995.

Johnson, Walter. Soul by Soul, Life Inside the Antebellum Slave Market. Cambridge: Harvard University Press, 1999.

Kein, Sybil, ed. Creole: the History and Legacy of Louisiana's Free People of Color. Baton Rouge: Louisiana State University Press, 2000.

Kmen, Henry. Music In New Orleans The Formative Years 1791-1841. Baton Rouge: Louisiana State University Press, 1966.

Lachance, Paul F. "The Foreign French." In Creole New Orleans: Race and Americanization, eds. Arnold R. Hirsch and Joseph Logsdon, 101-130. Baton Rouge: Louisiana State University Press, 1992.

Lincoln, Rixford J. Historical New Orleans: In Verse. New Orleans: s.n. 1911.

Logsdon, Joseph and Arnold Hirsh, eds., Creole New Orleans: Race and Americanization. Baton Rouge: Louisiana State University Press, 1992.

Long, Carolyn Morrow. A New Orleans Voudou Priestess: The Legend and Reality of Marie Laveau. Gainsville: University of Florida Press, 2006.

Martin, Joan M. "Plaçage and the Louisiana Gens de Couleur Libre: How Race and Sex Defined the Lifestyles of Free Women of Color." In Creole: the History and Legacy of Louisiana's Free People of Color, ed. Sybil Kein, 57-70. Baton Rouge: Louisiana State University Press, 2000.

Mills, Gary B. The Forgotten People: Cane River's Creoles of Color. Baton Rouge: Louisiana State University Press, 1977. 
Mills, Gary. "Coincoin: An Eighteenth-Century "Liberated" Woman." The Journal of Southern History, 42:2 (May 1976): 205-222.

Morlas, Katy Frances. "La Madame Et La Mademoiselle: Creole Women in Louisiana, 1718-1865." MA thesis, Louisiana State University, 2005.

Nash, Gary B. Red, White and Black: The Peoples of Early America. New Jersey: Englewood Cliffs, 1974.

Pascoe, Peggy. What Comes Naturally: Miscegenation Law and the Making of Race in America. Oxford: Oxford University Press, 2009.

Schweninger, Loren "Property-Owning Free African American Women in the South, 1800-1870," Journal of Women's History,1:3 (Winter, 1990): 13-44.

Spear, Jennifer. "Colonial Intimacies: Legislating Sex in French Louisiana." The William and Mary Quarterly 60:1 (Jan. 2003) : 75-98.

Thernstrom, Stephen ed. Harvard Encyclopedia of American Ethnic Groups. Cambridge, Mass.: Belknap Press of Harvard University, 1980.

Thompson, Shirley. " 'Ah, Toucoutou, ye conin vous': History and Memory in Creole New Orleans." American Quarterly 53 (June 2001): 232-266.

Usner, Daniel H. Indians, Settlers, \& Slaves in A Frontier Exchange Economy: The Lower Mississippi Valley Before 1783. Chapel Hill: University of North Carolina Press, 1992.

Van Kirk, Sylvia, Many Tender Ties: Women in Fur-Trade Society, 1670-1870. Norman: University of Oklahoma Press, 1980.

Voorhies, Jacqueline K. comp. Some Late Eighteenth-Century Louisianians: Census Records of the Colony, 1758-1796. Layette, La: University of Southwest Louisiana, 1973.

Walker, Juliet E.K. "Racism, Slavery, and Free Enterprise: Black Entrepreneurship in the United States before the Civil War." The Business History Review 60:30 (Autumn, 1986): 343-382.

White, Shane and Graham White. Stylin' African American Expressive Culture from Its Beginnings to the Zoot Suit. Ithaca: Cornell University Press, 1998. 
Wilson, Samuel Jr., ed. Southern Travels: Journal of John H.B. Latrobe, 1834. New Orleans: The Historic New Orleans Collection, 1986.

www.ibibio.org/laslave 